DOE/EA-1217

August 1997

\title{
Environmental Assessment
}

\section{Test Area North Pool Stabilization Project Update}




\section{DISCLAIMER}

Portions of this document may be illegible electronic image products. Images are produced from the best available original document. 


\section{U.S. DEPARTMENT OF ENERGY \\ FINDING OF NO SIGNIFICANT IMPACT FOR THE \\ TEST AREA NORTH POOL STABILIZATION PROJECT UPDATE AT THE IDAHO NATIONAL ENGINEERING AND ENVIRONMENTAL LABORATORY}

Agency: U. S. Department of Energy (DOE)

Action: Finding of No Significant Impact (FONSI)

The DOE Programmatic Spent Nuclear Fuel Management and Idaho National Engineering Laboratory Environmental Restoration and Waste Management Programs Final Environmental Impact Statement (DOE/EIS-0203-F), hereafter referred to as the SNF EIS, analyzed the cumulative environmental impacts of spent nuclear fuel management on the. Idaho National Engineering and Environmental Laboratory (INEEL). The Test Area North (TAN) Pool Stabilization Project was included in that analysis. In the Record of Decision (ROD) for the SNF EIS, DOE decided that the TAN Pool Stabilization Project would be deferred pending further project definition, funding priorities, or appropriate review under the National Environmental Policy Act (NEPA). To provide further detailed review under NEPA, DOE prepared the TAN Pool Stabilization Project Environmental Assessment (EA) DOE/EA-1050, issued May 6, 1996. The EA tiers from the SNF EIS and analyzes the potential environmental impacts of the TAN Pool Stabilization Project and reasonable alternatives, including the no action alternative in accordance with the Council on Environmental Quality Regulations (40 CFR Parts 1500-1508).

DOE has now updated the TAN Pool Stabilization Project EA and FONSI issued May 6, 1996. The purpose of the update is to include in the proposed action a "drying" process for the Three Mile Island (TMI) core debris canisters and certain other spent nuclear fuels currently stored underwater in the TAN pool. A license application to construct a dry storage facility for the TMI core debris, called an Independent Spent Fuel Storage Installation (ISFSI), was submitted to the Nuclear Regulatory Commission (NRC) on October 31, 1996. Information developed for the NRC license application identified the need to consider drying to remove free water retained in the TMI core debris canisters following their removal from underwater storage.

Proposed Action: The proposed action and the referenced sections of the EA (in parenthesis) are as follows: (a) removal of the TMI core debris, commercial fuel, and hardware from the TAN Storage Pool and dewatering and washing operations (Section 2.1.1); (b) drying operations to prepare materials for transport or storage (Section 2.1.2); (c) transportation of the fuel and debris to ICPP (Section 2.1.3) to be stored in an ISFSI that would be sited, constructed and operated at ICPP (Section 2.1.4); (d) decontaminating and recycling hardware to be reused, transporting hardware to be disposed of to RWMC for disposal (Sections 2.1.1 and 2.1.3); and (e) draining, decontaminating and stabilizing the TAN Pool and treating and disposing of the pool water (Section 2.1.5). The proposed action would take place at facilities located within the boundaries of the INEEL: TAN, the Radioactive Waste Management Area (RWMC), and the Idaho Chemical Processing Plant (ICPP). This activity will also require research, development, and testing of the systems to accomplish the proposed action. These systems include the removal, dewatering, and washing system; drying system; transportation system; storage system; and pool dewatering system. Information gained from this research and development will be used in the refinement of the system designs. 
Analysis: Based on the analysis contained in the EA, the proposed action would not have a significant effect on the human environment within the meaning of NEPA. The term

"significantly" and the significance criteria are defined by the Council on Environmental Quality (CEQ) Regulations for implementing NEPA at 40 CFR Section 1508.27. Each of the

significance criteria are addressed below and referenced to the corresponding analysis in the EA.

1) Beneficial and adverse impacts [40 CFR 1508.27 (b)(1)]:

- The proposed action will resolve potential vulnerabilities associated with the TAN pool (pp.1-5).

- The analysis indicates that there are few if any adverse impacts associated with implementing the proposed action concerning:

- Construction activities (pp. 21, 27-29);

- Radiation emissions and exposure (pp. 22-24, 27-31);

- Storage pool water treatment and discharge (pp. 23, 24);

- Generation of radioactive and nonradioactive wastes (pp. 23-25, 28);

- Socioeconomic factors (pp. 25, 29).

2) Public health and safety [40 CFR 1508.27 (b)(2)]:

- The analysis indicates that public exposure to radiation will be below levels known to cause adverse health effects (pp. 22-24).

- The analysis indicates that the highest probability of a cancer fatality in the public resulting from a "worst case" accident scenario is below the average cancer mortality rate (pp. 25-27).

- The analysis indicates that worker exposure during TMI canister handling, dewatering, drying, and transporting will be within limits established by DOE (pp. 23, 24).

3) Unique characteristics of the geographical area [40 CFR 1508.27 (b)(3)]:

- The analysis indicates that no unique characteristics of the geographical area will be impacted by the project (p. 29).

4) Degree to which effects on the quality of the human environment are likely to become highly controversial [40 CFR 1508.27 (b)(4)]:

- The analysis indicates that implementing the proposed action will result in no significant effects on the quality of the human environment.

5) Uncertain or unknown risks on the human environment [40 CFR 1508.27 (b)(5)]:

- The analysis indicates that no unique, uncertain, or unknown risks to, or effects on, the human environment will result from impacts associated with implementing the proposed action.

6) Precedent for future actions [40 CFR 1508.27 (b)(6)]:

- The project does not set a precedent for future actions that may have significant effects or represent a decision in principle about a future consideration.

7) Cumulatively significant impacts [40 CFR 1508.27 (b)(7)]:

- The analysis indicates that there are no impacts associated with implementing the proposed action which, when added to other past, present, and reasonably foreseeable future actions would result in a cumulatively significant environmental impact (pp. 28, 29). The 
cumulative impacts of reasonably foreseeable related actions have been evaluated in the SNF EIS. The interim storage of spent nuclear fuel at INEEL is addressed in Volume I of the SNF EIS and the impacts of the TAN Pool Stabilization Project are addressed in Volume II. The EA compliments the SNF EIS with additional detailed site and project specific description and environmental analysis.

8) Effect on cultural or historical resources [40 CFR 1508.27 (b)(8)]:

- No cultural resources are anticipated to be impacted (pp. 21, 25). The TAN Storage Pool and Hot Shop are eligible for listing on the National Register of Historic Places; however, this action will not modify these structures (p. 25).

9) Effect on threatened or endangered species or critical habitat [40 CFR 1508.27 (b)(9)]:

- The analysis indicates that no threatened or endangered species or critical habitat will be affected by implementing the proposed action (pp. 25, 32).

10) Violation of Federal, State, or Local law [40 CFR 1508.27 (b)(10)]:

- The analysis indicates that implementing the proposed action will not violate any federal, state, or local law (pp. 30, 31).

Determination: Based on the analysis presented in the attached EA, and on public comment received on the draft predecision $E A$, I have determined that the proposed action does not constitute a major Federal action significantly affecting the quality of the human environment. Therefore, preparation of an environmental impact statement is not required.

Issued at Idaho Falls, Idaho on this $25 \frac{t}{2}$ day of 1997.

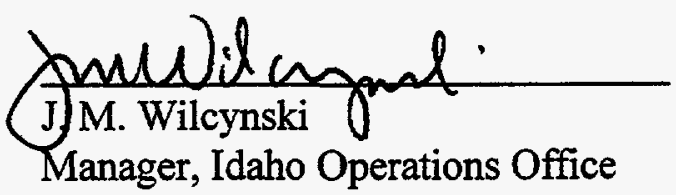

Copies of the EA and FONSI are available from: Brad Bugger, Office of Communications, MS-1214, Idaho Operations Office, U. S. Department of Energy, 850 Energy Drive, Idaho Falls, Idaho, $83403-3189$, or by calling (208) 526-0833 or the toll-free INEEL citizen inquiry line (800)708-2680.

For further information on the NEPA process contact: Roger Twitchell, NEPA Compliance Officer, MS-1216, U. S. Department of Energy, 850 Energy Drive, Idaho Falls, Idaho, 834033189, (208) 526-0776. 



\section{Environmental Assessment}

\section{Test Area North Pool Stabilization Project Update}

Published August 1997

U.S. Department of Energy DOE Idaho Operations Office Idaho Falls, Idaho 


\section{TABLE OF CONTENTS}

1. INTRODUCTION

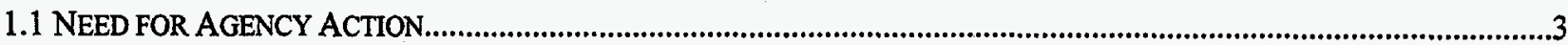

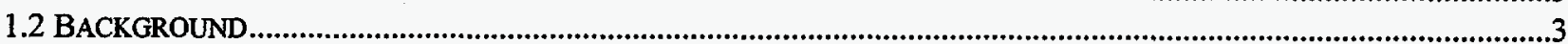

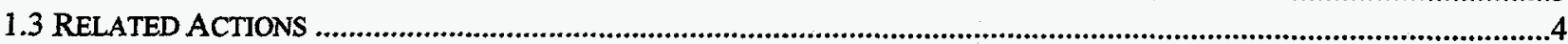

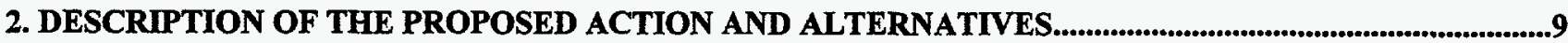

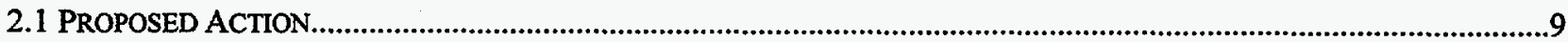

2.1.1 Removal of TM Debris, Commercial Fuel, and Hardware from the Pool ....................................................9

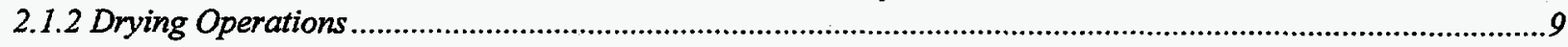

2.1.3 Transportation of TMI Canisters, Hardware, and Commercial Fuel .........................................................10

2.1.4 Independent Spent Fuel Storage Installation (ISFSI) ..............................................................................10

2.1.5 TAN Pool Draining and Decontamination Operations ................................................................................

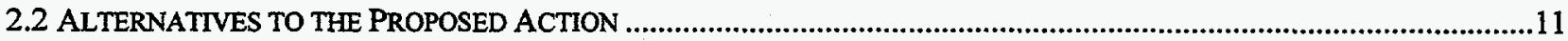

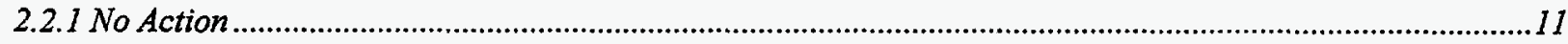

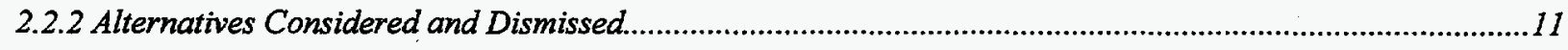

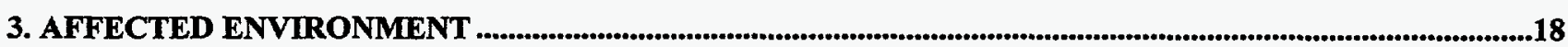

4. ENVIRONMENTAL IMPACTS

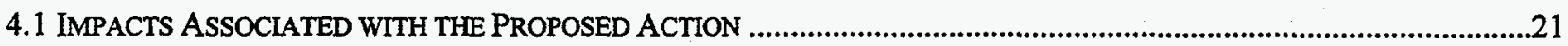

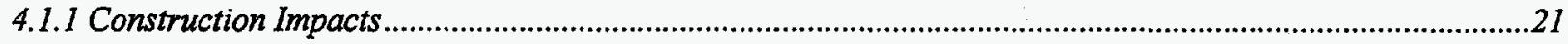

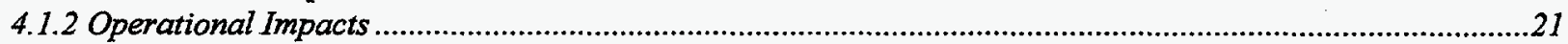

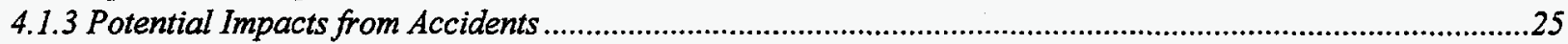

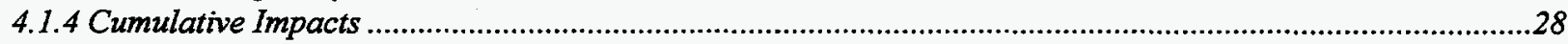

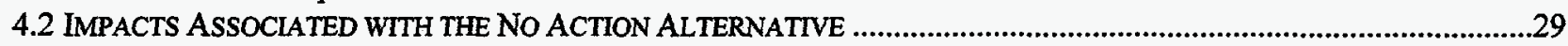

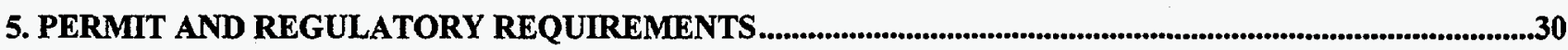

6. AGENCIES AND PERSONS CONSULTED

7. REFERENCES

\section{FIGURES}

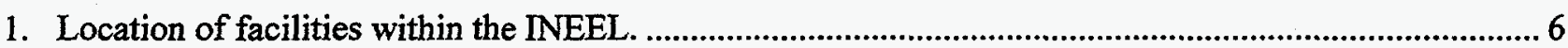

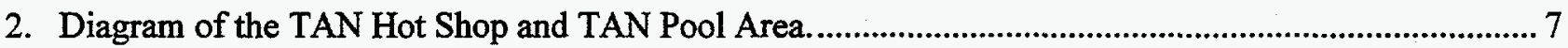

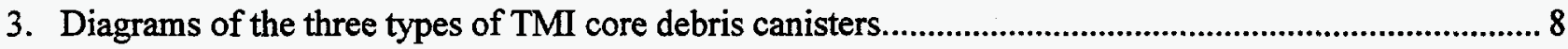

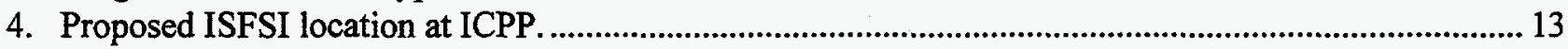

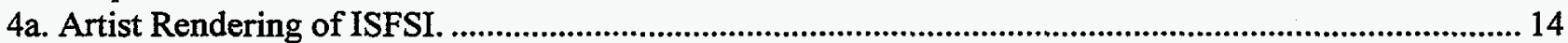

5. ISFSI Construction Site, TMI-2 ISFSI Pad and Storage Modules at ICPP ....................................... 15

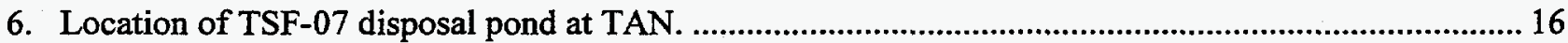

7. Location of the INEEL, Eastern Snake River Plain and the generalized flow direction of the Snake River

Plain Aquifer .

\section{TABLES}

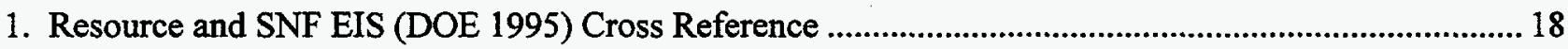

2. Potential Radionuclide Inventory and Releases ............................................................................22

3. EDE to MEI Due to Potential Airborne Releases from Existing Storage and the Proposed Action........ 23

4. Upper-bound estimates of airborne radionuclides (curies/accident) resulting from postulated accidents of the proposed action during Hot Shop operations.

5. Summary of radiological effects from releases under accident scenarios ...........................................22

6. Radiological Air Emission Baseline and Ten-year Dose (DOE 1995) ..................................................28 


\section{ACRONYMS AND ABBREVIATIONS}

ALARA as low as reasonably achievable

BAT best available technology

CAM constant air monitor

CFR Code of Federal Regulations

$\mathrm{Ci} \quad$ Curies

Co cobalt

Cs cesium

DCG derived concentration guide

DOE U.S. Department of Energy

DOE-ID U.S. Department of Energy-Idaho Operations Office

DOT U.S. Department of Transportation

EA Environmental Assessment

EDE : $\quad$ effective dose equivalent

EPA Environmental Protection Agency

FONSI Finding of No Significant Impact

FR Federal Register

$g$

acceleration due to gravity at sea level

$\mathrm{H}-3 \quad$ tritium

HEPA high efficiency particulate air

HLLW high-level liquid waste

I iodine

ICPP Idaho Chemical Processing Plant

IDAPA Idaho Administrative Procedures Act

IFSF Irradiated Fuel Storage Facility

INEL Idaho National Engineering Laboratory

INEEL Idaho National Engineering and Environmental Laboratory

ISFSI independent spent fuel storage installation (10 CFR 72)

ISS Interim Storage System

$\mathrm{Kr} \quad$ krypton

LET\&D Liquid Effluent Treatment and Disposal

LLW low-level waste

LITCO Lockheed Idaho Technologies Company

LOFT loss-of-fluid test

MCL maximum contaminant level

MEI maximally exposed individual

MPF maximum probable flood

mrem millirem 


\begin{tabular}{|c|c|}
\hline NEPA & National Environmental Policy Act \\
\hline NESHAP & National Emissions Standards for Hazardous Air Pollutants \\
\hline NHPA & National Historic Preservation Act \\
\hline NPDES & National Pollutant Discharge Elimination System \\
\hline $\mathrm{NRC}$ & U.S. Nuclear Regulatory Commission \\
\hline NSB & nearest site boundary \\
\hline PEW & Process Equipment Waste \\
\hline PSP & Pool Stabilization Project \\
\hline PTC & Permit to Construct \\
\hline RAM & remote air monitor \\
\hline RCRA & Resource Conservation and Recovery Act \\
\hline RSAC & Radiological Safety Analysis Computer Program \\
\hline ROD & Record of Decision \\
\hline RWMC & Radioactive Waste Management Complex \\
\hline SHPO & State Historic Preservation Officer \\
\hline SNF & spent nuclear fuel \\
\hline SNF EIS & $\begin{array}{l}\text { Department of Energy Programmatic Spent Nuclear Fuel Management and Idaho National } \\
\text { Engineering Laboratory Environmental Restoration and Waste Management Programs Final } \\
\text { Environmental Impact Statement }\end{array}$ \\
\hline TAN & Test Area North \\
\hline TSF & Technical Support Facility \\
\hline TMI & Three Mile Island \\
\hline USGS & United States Geological Survey \\
\hline VDS & vacuum drying system \\
\hline W & watts \\
\hline WINCO & Westinghouse Idaho Nuclear Company \\
\hline
\end{tabular}




\section{GLOSSARY}

As low as reasonably achievable (ALARA): An approach to radiation protection to control or manage exposures (both individual and collective to the work force and the general public) and releases of radioactive material to the environment as low as social, technical, economic, practical, and public policy considerations permit.

Beyond design basis accident: An accident of the same type as a distinct design basis accident (fire, earthquake, etc) but defined by parameters that exceed in severity the parameters defined for the design basis accident.

Coffin: The box, case, or structure in which a fuel assembly is placed for safe storage. The outer dimensions are sized to ensure criticality safety when several coffins are stored together.

Criticality: An expression of the ability of a fission reaction to sustain itself based on the change in the number of neutrons engaging in the fission reaction, with each such neutron being responsible for a fission event. Since not all neutrons result in a fission event (some escape or are absorbed without resulting in a fission event), a self-sustained reaction requires enough neutrons to be produced in the fission events to sustain the reaction rate after accounting for losses. Such a balanced, equilibrium situation is referred to as a critical reaction, which is self-sustaining (does not need an outside neutron source) and stable (the fission rate is neither increasing nor dropping off).

Curie (Ci): A unit of radioactivity equal to 37 billion disintegrations per second; also a quantity of any radionuclide or mixture of nuclides having one $\mathrm{Ci}$ of activity.

Decontaminate (Decontamination): The removal or immobilization of radioactively contaminated particles.

Derived concentration guide (DCG): The concentration of a radionuclide in air or water that, under conditions of continuous exposure for 1 year by one exposure mode (i.e., ingestion of water, submersion in air, or inhalation), would result in an effective dose equivalent of $100 \mathrm{mrem}(0.1 \mathrm{rem})$.

Design basis accident: Accidents that are postulated for the purpose of establishing functional requirements for safety of significant structures, systems, components, and equipment.

Dewatered Canister: A dewatered canister is one in which a majority of the free standing water has been removed.

Dried Canister: A dried canister has had moisture removed (driven off) in order to meet the acceptance criteria for storage in an ISFSI. Moisture removal is accomplished using a physical process, such as a heated vacuum system, to remove the excess moisture.

Effective dose equivalent (EDE): The sum of the products of absorbed dose and appropriate factors to account for differences in biological effectiveness caused by the quality of radiation and its distribution in the body of a reference man. The unit of the effective dose equivalent is the roentgen equivalent man (rem).

High-efficiency particulate air (HEPA) filter: A disposable filter having a minimum removal efficiency of $99.97 \%$ for 0.3 micron or larger particles.

Ion: An electrically charged atom or group of atoms. The electrical charge results when a neutral atom or group of atoms loses or gains one or more electrons. The loss of electrons results in positively charged ions (cations), the gain of electrons results in negatively charged ions (anions). 
Isotope: One of two or more atoms with the same number of protons, but different numbers of neutrons, in their nuclei. Thus, carbon-12, carbon-13, and carbon-14 are isotopes of the element, carbon, the numbers denoting the approximate atomic weights. Isotopes have very nearly the same chemical properties, but often different physical properties (for example, carbon-12 and -13 are stable, carbon-14 is radioactive).

Ion exchange: A reversible process in which a solution passes over a medium that removes the soluble ions by exchanging them with labile (unstable) ions from the medium.

Maximum contaminant levels (MCLs): Environmental Protection Agency standards for contaminants in public drinking water that may have an adverse effect on people's health.

Maximally exposed individual (MED): A hypothetical individual defined to allow dose or dosage comparison with numerical criteria for the public. This individual is located at the point on the INEEL site boundary nearest to the facility in question.

Radiation absorbed dose (rad): The basic unit of absorbed dose equal to absorption of 0.01 joule per kilogram of absorbing material.

Radiolysis: Decomposition of water to form hydrogen and oxygen when subjected to a radiation environment.

Radioisotope: An unstable isotope of an element that decays or disintegrates spontaneously, emitting radiation. Approximately 5,000 natural and artificial radioisotopes have been identified.

Radionuclide: See radioisotope

Roentgen equivalent man (rem): The dosage of ionizing radiation that will cause the same biological effect as one roentgen of $\mathrm{x}$-ray or gamma-ray exposure.

- millirem is a unit equal to $1 / 1000$ th of a rem.

- person-rem is a unit of collective radiological dose or the collective total dose to a population and is calculated by summing the individual doses to each member of the given population. For instance, if a population of 100 people receive $0.1 \mathrm{rem}$, then the collective dose would be 10 person-rem (100 persons $\times 0.1 \mathrm{rem}$ ).

Sizing: The process of reducing the size of various types of solid wastes by compaction, melting, or cutting.

Stabilize (Stabilization): To place the pool in a safe, nonoperable condition, suitable for refurbishment or eventual decommission. The TAN Pool is considered to be stabilized once all of the fuel-bearing and other radioactively contaminated materials are removed from the pool, the pool water is removed, and the remaining pool surfaces are decontaminated (see Glossary) to a level reflective of the remainder of the Hot Shop.

Water of hydration: Water of hydration, sometimes called bound water, consists of water molecules held in the crystalline structure of cement by electrostatic bonds. Similar to free water, waters of hydration may be removed by heating, but at higher temperatures. 


\section{UNIT PREFIXES}

\begin{tabular}{lllc} 
Prefix & Power & \multicolumn{1}{c}{ Value } & Symbol \\
mega & $10^{6}$ & $1,000,000$ & $\mathrm{M}$ \\
kilo & $10^{3}$ & 1,000 & $\mathrm{k}$ \\
centi & $10^{-2}$ & 0.01 & $\mathrm{c}$ \\
milli & $10^{-3}$ & 0.001 & $\mathrm{~m}$ \\
micro & $10^{-6}$ & 0.000001 & $\mu$ \\
nano & $10^{-9}$ & 0.000000001 & $\mathrm{n}$ \\
pico & $10^{-12}$ & 0.000000000001 & $\mathrm{p}$ \\
femto & $10^{-15}$ & 0.000000000000001 & $\mathrm{f}$
\end{tabular}

CONVERSION TABLE

English

1 foot

1 cubic foot

1 gallon

1 mile (5280 feet)
Metric

0.3048 meters

0.02832 cubic meters

3.785 liters

1609 meters 


\section{INTRODUCTION}

The purpose of this Environmental Assessment (EA) is to update the "Test Area North Pool Stabilization Project" EA (DOE/EA-1050) and finding of no significant impact (FONSI) issued May 6, 1996. A predecision draft of that EA was released for a 30 day public review and comment period on February 20,1995 . It was then revised in response to public comment, and re-released for an additional 30 day public review and comment period, along with a draft FONSI on May 10, 1995. The EA and FONSI were revised in response to public comment and issued as noted above, on May 6, 1996.

This update analyzes the environmental and health impacts of a "drying" process for the Three Mile Island (TMI) nuclear reactor core debris canisters now stored underwater in a facility on the Idaho National Engineering and Environmental Laboratory (INEEL). A drying process was analyzed in the predecision versions of the EA released in 1995 but that particular process was determined to be ineffective and dropped from the EA/FONSI issued May 6, 1996. A new drying process was subsequently developed and is analyzed in Section 2.1 .2 of this document. Sections of this EA with new information, scope, or a change in impacts are identified by a bar (line) at the left margin of the page. In addition, drawings and site plans in this EA have been updated based on additional information that has been developed and to provide clarity. Minor revisions in the document to improve readability, correct grammatical or typographical errors, or provide technical consistency in terminology (e.g., changing the INEL to INEEL or ISS to ISFSI) have not been marked.

A predecision version of this updated EA/FONSI, dated June 1997, was made available for a 30 day comment period on June 25, 1997. Notification of the public comment period was provided in a legal notice printed in newspapers used for identification of INEEL activities, a media press release, and announcements sent to INEEL stakeholders who requested notification of NEPA activities. As identified in the press release and public notices, copies of the predecision document were available for review in the government section of libraries and INEEL offices, by calling the INEEL's toll-free number, or by writing the project manager. During the comment period, personnel from the State of Idaho's INEEL Oversight Program contacted DOE-ID project personnel to discuss the proposed activity including technical details of the project and potential accident risks. At the close of the comment period, no comments were received on the predecision EA/FONSI. The paragraphs or footnotes in this EA that were revised based on internal DOE comments are identified by a bold bar (line) at the left margin of the page. Changes include:

1) clarifying and providing consistency in the discussion of the proposed action's scope in Section 2.1 and the FONSI;

2) revising Section 1.2 "Background" to identify the volume of SNF in the pool and compare it to the volume evaluated in the SNF EIS Record of Decision (DOE 1995a);

3) combining the discussion of the Settlement Agreement in Sections 1.0 and 1.1.

4) adding Figure $4 \mathrm{a}$, an artist's rendition of an ISFSI;

5) adding a footnote to Table 3 to clarify the assumptions and background information used to develop the calculations;

6) adding a discussion of 10 CFR 1022 requirements to Section 3;

7) revising Section 4.1.3.3 to provide additional detail about ISFSI features designed to protect the canisters from damage during potential accidents;

8) revising Section 5 "Permit and Regulatory Requirements" to identify the NRC regulatory basis;

9) adding Executive Order 11988 (Floodplain Management), Executive Order 11990 (Protection of Wetlands), and Executive Order 12898 (Environmental Justice) to Section 5; 
As did the $1996 \mathrm{EA}$, this update analyzes the environmental and health impacts of removing various radioactive materials from underwater storage, dewatering these materials, constructing a new interim dry storage facility, and transporting and placing the materials into the new facility. Also, as did the $1996 \mathrm{EA}$, this EA analyzes the removal, treatment and disposal of water from the pool, and placement of the facility into a safe, standby condition. The entire action would take place within the boundaries of the INEEL. The materials are currently stored underwater in the Test Area North (TAN) building 607 pool, the new interim dry storage facility would be constructed at the Idaho Chemical Processing Plant (ICPP) which is about 25 miles south of TAN, see Figure 1. The materials that would be removed from underwater storage and placed into dry storage include nuclear reactor core debris from the 1979 TMI Unit II reactor accident, nuclear fuel rods and assemblies from Loss-of-Fluid Test (LOFT) reactor tests that took place on the INEEL, and government owned commercial fuel rods, assemblies and hardware from various sources. The LOFT and government owned commercial fuel rods and assemblies are hereafter referred to in this EA collectively as "commercial fuels" except where distinction between the two is important to the analysis.

This EA tiers from the DOE Programmatic Spent Nuclear Fuel Management and Idaho National Engineering Laboratory Environmental Restoration and Waste Management Programs Final Environmental Impact Statement (DOE/EIS-0203-F), hereafter referred to as the SNF EIS (DOE 1995). The proposed action addressed by this EA was also addressed in the SNF EIS as follows:

- Vol. 2. Part A, Table 2.2-1 Corrective Actions for Addressing Spent Fuel Vulnerabilities-Test Area North

- Vol. 2, Part A, Table3.1-2 Spent Nuclear Fuel-Related Projects at the INEL (TAN Pool Stabilization Project considered in alternatives $A, B$, and $D$, discussion throughout Sec. 3.1)

- Vol. 2, Sec. 3.3 Comparison of Impacts

- Vol. 2, Sec. 3.4 Preferred Alternative

- Vol. 2, Part 2, Appendix C-2.1 Test Area North Fuel Transfer.

In May of 1995, the State of Idaho asked the District Court to continue the prior injunction against SNF transportation by the Department of Energy, claiming that the SNF EIS was defective. This litigation was settled between DOE, the Department of the Navy and the State of Idaho. On October 17, 1995, the Federal District Court entered a Court Order that incorporated, as requirements, the terms and conditions of the parties' in a Settlement Agreement (DOE 1995b). Paragraph E7 of the Settlement Agreement states that "DOE shall complete construction of the Three Mile Island dry storage facility by December 31, 1998. DOE shall commence moving fuel into the facility by March 31, 1999, and shall complete moving fuel into the facility by June 1,2001." Among the terms and conditions of the Settlement Agreement is the requirement to transfer all spent nuclear fuel out of wet storage, to request funds to replace wet storage, and to commence spent fuel loading into dry storage by July 1, 2003. The proposed action analyzed in this EA is consistent with, and preparatory to, meeting those terms and conditions.

This EA is prepared in accordance with Council on Environmental Quality (CEQ) Regulations for implementing the National Environmental Policy Act (NEPA) at 40 CFR 1500, and DOE NEPA Implementing Procedures at 10 CFR 1021. In addition to the proposed action, this EA analyzes the No Action alternative, and the following alternatives: (a) Refurbish the TAN Pool, (b) Construct a New Wet (underwater) Storage Facility, (c) Store the TMI Core Debris Canisters and Commercial Fuels in Existing ICPP Storage Systems (d) Construct an Independent Spent Fuel Storage Facility at a Point Removed From Above the Snake River Plain Aquifer, and (d) Construct an Independent Spent Fuel Storage Facility at TAN. These alternatives are described in Section 2.2. 


\subsection{Need for Agency Action}

- DOE has identified, and proposes to eliminate vulnerabilities associated with SNF storage facilities [Spent Fuel Working Group Report on Inventory and Storage of the Department's Spent Nuclear Fuel and Other Reactor Nuclear Material and Their Environmental, Safety, and Health Vulnerabilities (DOE 1993a)]. Vulnerabilities that were originally identified for TAN are storage of SNF in an unlined pool, wet storage of commercial SNF in aluminum coffins, and seismic inadequacy of the pool.

- Compliance with the terms and conditions of the Settlement Agreement as discussed in Section 1.0.

- The TAN Pool does not meet SNF storage requirements delineated in U.S. Department of Energy (DOE) Order 420.1 "Facility Safety" (DOE 1995c). Principal deficiencies of the TAN Pool include lack of redundant containment of pool water (i.e., stainless steel pool liner), no provisions for detecting subsurface leaks from the pool, and inadequate control of the air space over the pool.

\subsection{Background}

The TAN-607 facility, which includes the TAN Pool and Hot Shop (Figure 2), was constructed in 1954. The TAN Pool was designed to store radioactive materials and is presently loaded to nearly $100 \%$ of useable capacity with the TMI core debris canisters, commercial fuels, and hardware (DOE 1993a). In August of 1993, the Secretary of Energy commissioned a comprehensive baseline study of the environmental, safety, and health vulnerabilities associated with the storage of SNF in the DOE complex. A multidisciplinary working group comprised of DOE employees and contractors evaluated the inventory and condition of DOE's reactor-irradiated nuclear material, which includes SNF and reactorirradiated target material. The working group also evaluated the condition of facilities that store SNF and identified the vulnerabilities and problems associated with these facilities. Vulnerabilities identified at TAN include inadequate corrosion monitoring, lack of leak detection and leak trending of the pool water inventory and a potential deficiency in the seismic design of the basin (DOE 1993a). DOE issued a Phase I Plan of Action to address SNF storage vulnerabilities in February 1994 (DOE 1994a), a Phase II Plan of Action in April 1994 (DOE 1994b), and a Phase III Plan of Action in October 1994 (DOE 1994c). The TAN Pool Stabilization Project addresses vulnerabilities identified in these plans.

The TAN Hot Shop is a large shielded high bay with overhead cranes, a large overhead manipulator, auxiliary wall mounted manipulators, and other equipment for remotely handling radioactive material. The Hot Shop is designed for the examination, testing, and monitoring of SNF, storage casks, and radioactive materials. The TAN Pool consists of the pool and a vestibule, an extension of the TAN Pool. A submerged passageway with an underwater rail system and transfer cart connects the vestibule to the main TAN Pool. The top of the passageway is $5 \mathrm{ft}$ underwater to protect the main pool area from potential radiation sources in the Hot Shop and to isolate the air exchange between the Hot Shop and TAN Pool. The Hot Shop also contains a silo, which is a shielded enclosure used for temporary storage of SNF assemblies and other radioactive materials.

The canisters containing the TMI core debris are stored in a fully flooded and vented condition in the TAN Pool. During defueling operations at the TMI-2 plant, the debris was placed in three types of cylindrical stainless-steel canisters: fuel, knockout, and filter (Figure 3). The fuel canisters are receptacles for large pieces of core debris, the knockout canisters were designed to contain smaller debris, and the filter canisters contain stainless-steel filters and fines that were collected in the filters during defueling operations. Neutron absorbing materials (boron carbide poison in the form of plates or

a Subsequent studies have determined that a design basis seismic event will not result in cracking or leaking of the TAN Pool as discussed in Section 4.2 (Lacey 1994). 
rods) were designed into each type of canister to prevent criticality events. The canisters, placed in the TAN Pool between 1986 and 1990, are currently stored in a six-pack configuration in stainless-steel storage modules lined with poison plates.

The TMI core material contained in the canisters is not typical of normal commercial fuels with intact fuel assemblies or fuel rods. The TMI core material is an agglomerate of the various items that existed within the reactor vessel after the accident. Due to the unique (damaged) nature of the core material, it was placed in specially designed canisters for transport from the TMI reactor to Idaho for storage. The damaged condition of the fuel, gas generation potential, low heat load, and relatively low volatile fission product inventory differentiate the debris from normal SNF. Due to the debris' characteristics and degree of water removal, it may be stored in a vented configuration or in a storage system designed to accommodate the generation of combustible gases. Intact (non-damaged) commercial fuels also have low decay heat loads; however, because volatile fission products are contained in the fuel rod cladding, vented dry storage is not required.

In a wet storage condition, the TMI canisters must vent to release radiolytic generated hydrogen and oxygen. Venting is accomplished through a vent orifice located in the top of each canister. Orifices were sealed using protective caps for canister shipment from TMI in Pennsylvania to the INEEL. The canisters were received at TAN and placed in the TAN Pool, the protective caps removed, and the canisters flooded with demineralized water. To allow gases generated within the canisters to escape, the vent port on each canister was connected to a water filled vent tube that extends upwards and out of the pool water surface.

The LOFT fuel assemblies originated at the LOFT facility at TAN. LOFT was a scaled-down version of a commercial pressurized water reactor where tests were conducted from 1976-1985. When the LOFT tests were completed, the fuel assemblies were taken to the Hot Shop and placed in modified TMI sixpack containers for underwater storage in the TAN pool. There are 13 complete LOFT fuel assemblies and 13 small containers (approx.10" x 10" x 12") of fuel remnants from one LOFT Fuel Assembly.

The commercial fuels, which were brought to the INEEL for research and development purposes, consist of fuel rods and assemblies from commercial water reactors. The fuels consist of a $10 \times 10$ array of aluminum storage racks containing 35 individual fuel rods, seven aluminum fuel storage coffins (see Glossary) holding a total of six fuel rod assemblies and a loose fuel rod basket. Miscellaneous hardware that would be removed from the pool after removing the TMI canisters and commercial fuels is identified in Section 2.1.1.

The TAN Pool contains an estimated spent nuclear fuel inventory of 85.29 metric tons of heavy metal ${ }^{\mathrm{b}}$ (LMITCO 1997). The INEEL inventory in 1995 was 261 metric tons and the projected inventory in 2035 is 426 metric tons (DOE 1995a).

\subsection{Related Actions}

On December 26, 1996, the Department of the Navy, as lead agency, and the Department of Energy, (as a cooperating agency), signed a Record of Decision (ROD) based upon the environmental information and analyses developed in preparing the Department of the Navy's Environmental Impact Statement (EIS) for a Container System for the Management of Naval Spent Nuclear Fuel. The ROD identified the agencies' decision to implement the preferred alternative (dual purpose canisters) identified in the final EIS dated November 1996. The Navy will use a dual-purpose canister system for the management of naval spent nuclear fuel and the management of naval special case low-level radioactive waste. A dual-

\footnotetext{
"A "metric ton of heavy metal" is a common unit of measure for spent nuclear fuel, which is 1,000 kilograms (2,200 pounds) of heavy metal (uranium, plutonium, thorium) contained in the spent fuel.
} 
|purpose canister system will be used for the loading, dry storage, transport, and possible disposal of naval spent nuclear fuel following examination at the INEEL. The EIS considered 6 container system alternatives for the management of Navy SNF. In a second ROD for the Navy SNF, issued on April 16, 1997, the Navy and DOE announced the decision to load the naval spent nuclear fuel which is, or which will be, stored at the ICPP, into dual purpose canisters at the Naval Reactors Facility (NRF) at the INEEL. The ROD announced the additional decision that all dual purpose canisters loaded with naval spent nuclear fuel and special case waste will be placed in an interim dry storage facility to be contructed at the NRF (See Figure 1). The alternatives addressed in the Navy EIS and this EA both consider the dry storage of SNF on the INEEL. Therefore the actions addressed by these two NEPA documents are related but not connected or dependent on one another.

In October, 1996, the DOE applied to the NRC for an ISFSI license for the TMI debris storage at the ICPP. As needed, this license will be amended by DOE to provide for storage of other SNF types at ICPP. The NRC's decision to license the receipt, transfer, and possession of spent fuel at the INEEL is subject to an independent NEPA evaluation in accordance with 10 CFR 51.10 (b). 


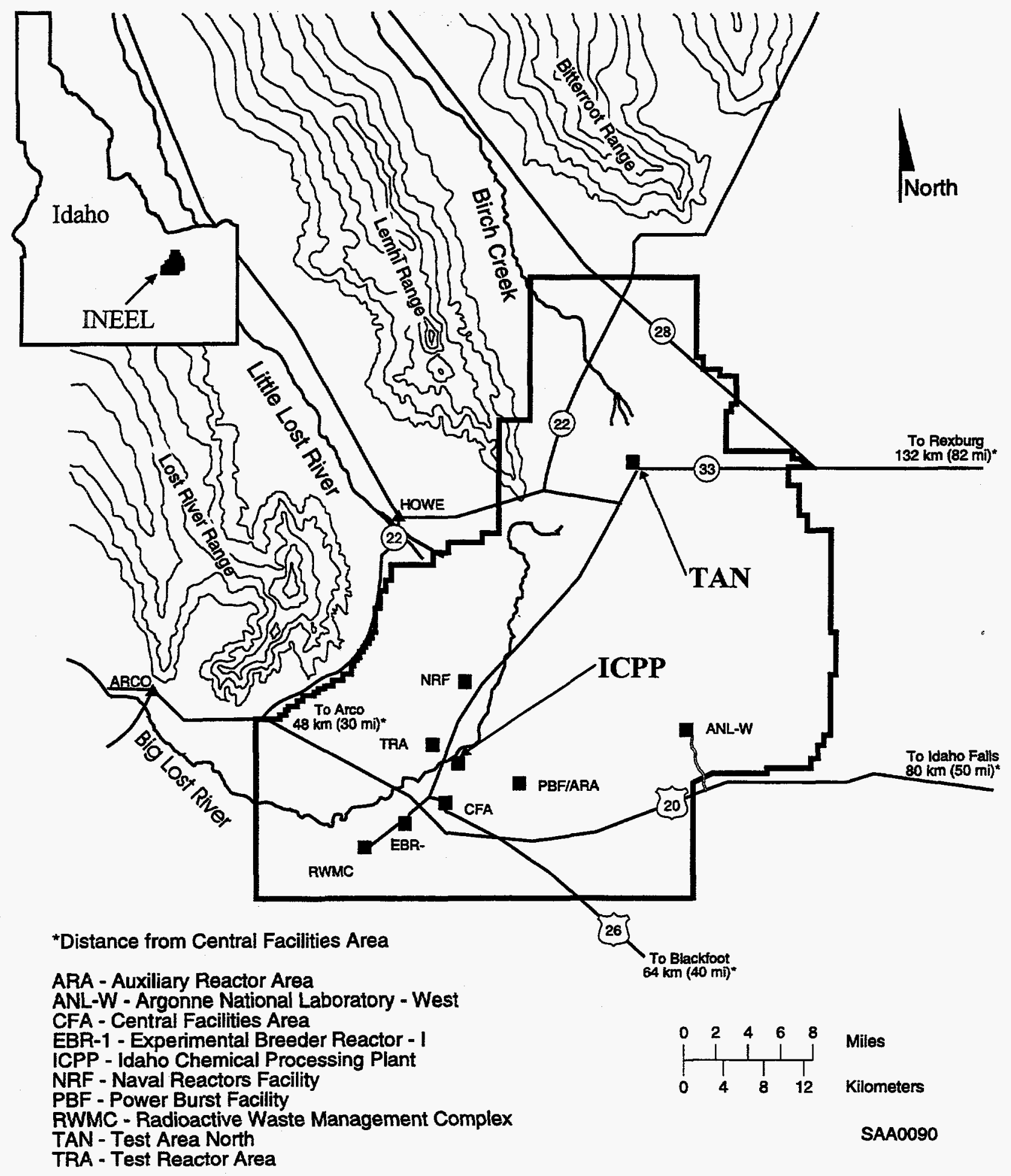

Figure 1. Location of facilities within the INEEL. 


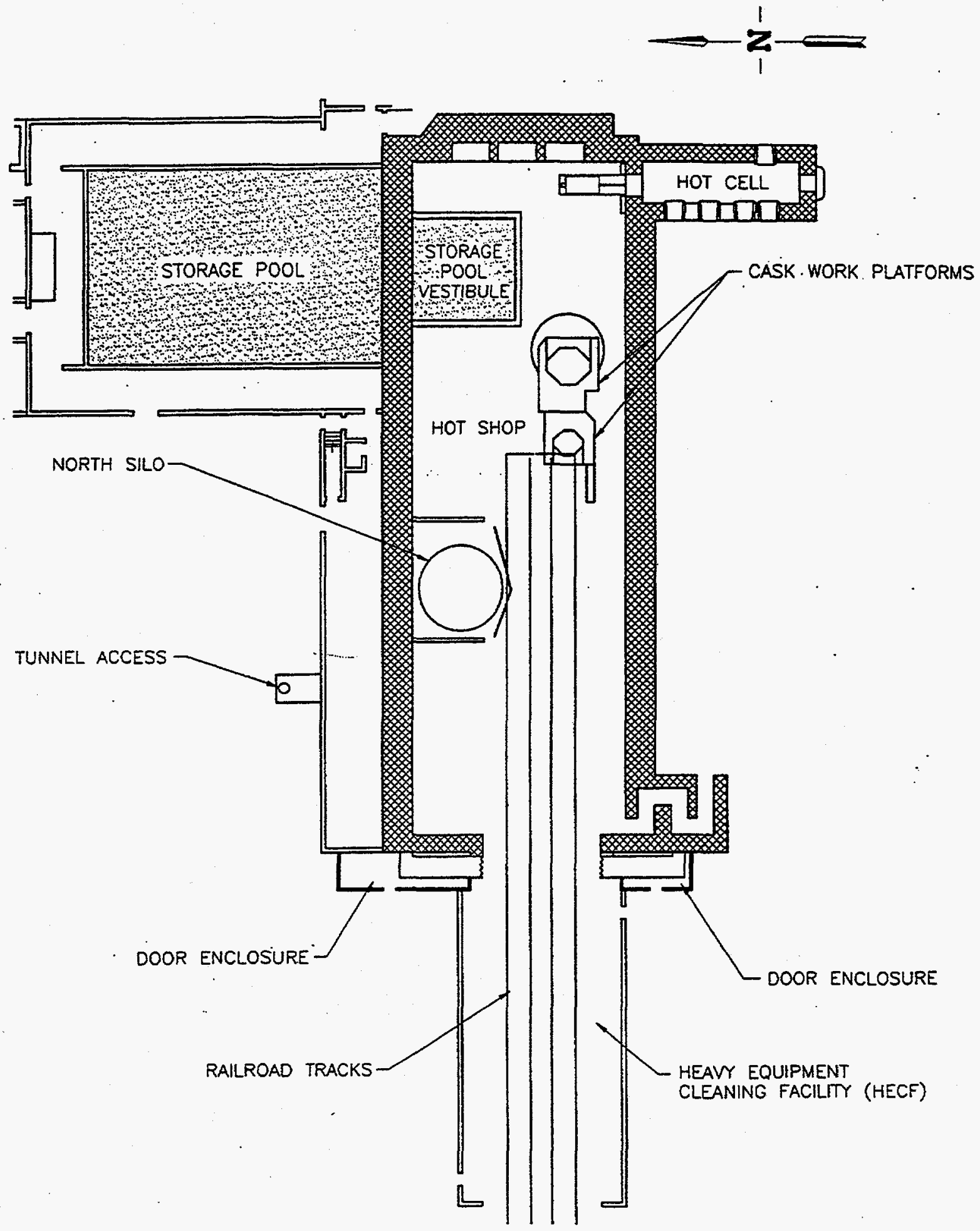

Figure 2. Diagram of the TAN Hot Shop and TAN Pool Area 


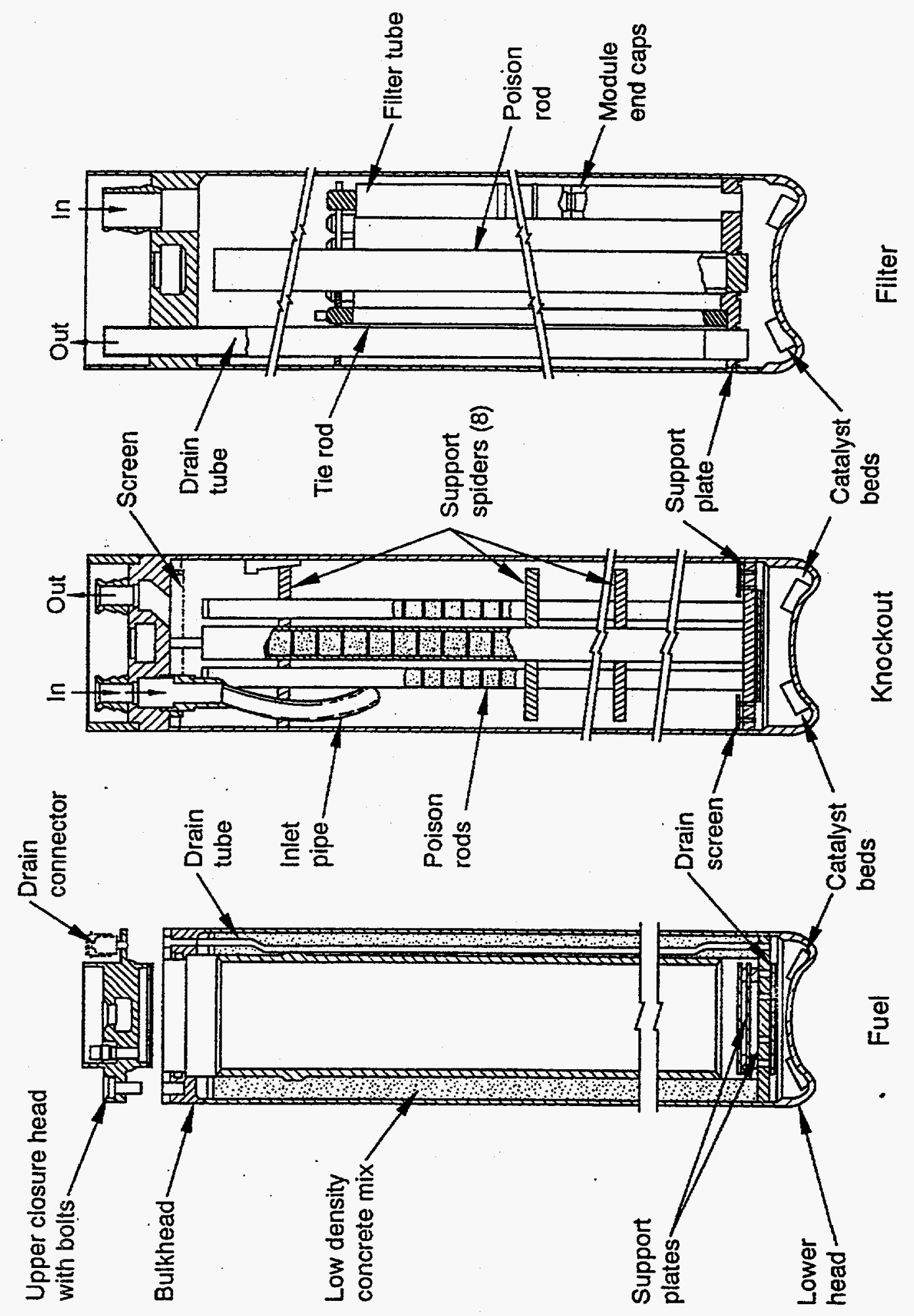

Figure 3. Diagrams of the three types of TMI core debris canisters. 


\section{DESCRIPTION OF THE PROPOSED ACTION AND ALTERNATIVES}

\subsection{Proposed Action}

The proposed action is to remove the TMI core debris, commercial fuel, and hardware from the TAN Storage Pool and provide for dewatering, washing, and drying operations as necessary in preparation for transport and storage. The TMI canisters and commercial fuels would be transported to ICPP for storage in an ISFSI. The ISFSI would be an above-ground storage system that would be sited, constructed, and operated at ICPP. Reusable hardware would be decontaminated (see Glossary) and the remaining hardware would be removed and transported to RWMC for disposal as low-level radioactive waste (LLW). The TAN Pool would be drained and the pool water would be treated and disposed of by one of several options discussed in Section 2.1.5. Following removal of the water, the empty pool would be decontaminated and the pool would be stabilized (see Glossary). The proposed action would be completed within approximately 10 years. Any future proposals for the TAN Pool or the Hot Shop would undergo subsequent NEPA review.

\subsubsection{Removal of TMI Debris, Commercial Fuel, and Hardware from the Pool}

While submerged in the pool, the TMI canisters would be dewatered (see Glossary). To dewater, the canisters would be purged with a gas (such as air, nitrogen or argon) to displace the majority of free water in the canister. After dewatering there would still be approximately 20 gallons of free water in each canister, intermingled in the fuel debris and the canister hardware. Air emissions from dewatering would be routed through a HEPA filter that would be installed as part of the dewatering system. The filtered air would be discharged to the Hot Shop and vented through the Hot Shop HEPA system to the TAN-734 stack. Once the canisters have been dewatered, they would be removed from the pool and prepared for drying in the Hot Shop.

The commercial fuels would be removed from the Storage Pool, washed to remove loose surface contamination, and suspended in the Hot Shop to dry prior to placement into dry storage. The commercial fuels may be staged in the shielded silo within the Hot Shop or in an existing dry storage cask located on the existing pad at TAN prior to transport to a dry storage facility.

The hardware to be removed from the Pool includes the TMI six-pack storage containers and poison plates, the LOFT six-pack containers, fuel storage coffins, the $10 \times 10$ storage rack array, and the LOFT upper core support structures. Equipment with potential value for reuse would be decontaminated and the remaining hardware would be transported to RWMC for disposal as LLW.

\subsubsection{Drying Operations}

After the TMI canisters are dewatered, the canisters would be dried further to remove the remaining free water in each canister. The benefits of removing this additional water would be two-fold. First and foremost, the criticality safety analysis requirements during transport/storage of the canisters would be assured due to the fact that the remaining free water was removed, and second, water removal would also simplify operations during storage by reducing or possibly eliminating radiolysis (see Glossary). Like the TMI canisters, it may also be necessary to dry the commercial fuels that have been disrupted (fuel purposely tested to disruption, such as the LOFT reactor fuel; fuel rods that failed during normal reactor operations and were subsequently transported to the INEEL for research; and fuel rods that were cut for examination purposes).

As noted in Section 2.1.1, it is estimated that up to 20 gallons of free water could remain in a canister after dewatering. In addition to the free water inside the canisters, the fuel type canisters (Figure 3) contain a liner constructed of a light-weight refractory cement (Manufacturer's name is LICON). The LICON contains free water not removed by the dewatering process. The LICON cement also contains water, consisting of pore water, and water of hydration (see Glossary) which is bound in the LICON. 
The free water in the core debris and the LICON would be removed by heating the canisters in a portable Vacuum Drying System (VDS). Because of the water bound in the LICON, the application of heat up to $600-1000^{\circ} \mathrm{F}$ would be required to release it from the chemical bonds of the cement. The VDS would be used to remove as much of the remaining free water as possible. The exact level of dryness achieved for each canister would be the result of testing and analysis, and the acceptance criteria would be documented in the TMI ISFSI Safety Analysis Report.

Conceptually, the VDS would have an electrically-powered furnace to provide the heat source. Ancillary equipment such as monitors, controllers, condensers, vacuum pump, etc. would be mounted on a skid adjacent to the furnace. The VDS would perform heat and vacuum assisted water removal on one to four canisters concurrently. Following dewatering, canisters would be removed from the pool and placed into the vacuum furnace using the existing overhead crane system. The vacuum furnace would be sealed and heated to approximately $600^{\circ} \mathrm{F}\left(1,000^{\circ} \mathrm{F}\right.$ maximum $)$ while operating the vacuum pump. This operation would be conducted until the required level of dryness to meet the ISFSI acceptance criteria is obtained. Emissions from the VDS would be condensed and cooled, the air emissions would be exhausted through a HEPA filter and the water emissions would be routed through a filter and ion exchange system and be returned to the TAN Pool system. The TAN Safety Analysis Review would be revised to ensure the safe operation of the drying system in the Hot Shop.

\subsubsection{Transportation of TMI Canisters, Hardware, and Commercial Fuel}

After removing the water from the canisters and fuels, they would be loaded into DOT approved casks for shipment to ICPP. Transportation of the TMI canisters and commercial fuel from TAN to ICPP would require an estimated 30 to 40 shipments. The distance from TAN to ICPP is approximately 25 miles which includes 5 miles of public road, Idaho Highway 33. Hardware to be disposed of at RWMC as LLW (see Section 4.1.2.3.2) would be placed in boxes and transported approximately 31 miles to RWMC.

\subsubsection{Independent Spent Fuel Storage Installation (ISFSI)}

The ISFSI would be a dry, above-ground SNF storage system which is based on an existing NRC topical license adapted to the unique features of the TMI debris (disrupted fuel in existing storage canisters) and commercial fuel. The ISFSI would be designed to (a) receive the transport cask, (b) transfer the debris and commercial fuels from the transport cask into storage, (c) store the canisters and commercial fuels, (d) allow inspection and monitoring of key safety parameters during storage, and (e) provide for retrievability of the canisters and commercial fuels to allow ready retrieval of SNF for further processing or disposal (10 CFR 72.122). A vacant storage position in the ISFSI or a transport cask would be maintained for overpacking or retrieval of canisters. Figure 4a depicts an artist rendition of an ISFSI.

The ISFSI would be located near CPP-666 (Figure 4) in an area that would accommodate access. Figure 5 depicts the plan view of the TMI-2 ISFSI submitted to the NRC for licensing. The ISFSI pad would require approximately one acre and the design would incorporate shielding and design features for safe operation. It would be designed to accommodate combustible gas, specifically hydrogen and oxygen generated by radiolysis (see Glossary) below explosive levels. Any gases generated in the canisters would pass through a HEPA filter prior to release to the atmosphere. Constant air monitors (CAMs), remote air monitors (RAMs), and passive air monitoring systems would be used, if required by the NRC safety analysis.

\subsubsection{TAN Pool Draining and Decontamination Operations}

The TAN Pool (including the vestibule) would be drained, then decontaminated and stabilized. The pool water would be sampled and a treatment and disposal option would be selected based on sample analysis and effectiveness in achieving compliance with regulatory requirements (see Section 5.0 for Permit and Regulatory Requirements), Water treatment and disposal options include: 
a) Reducing the volume of water through an evaporative process at TAN and transporting the residues to ICPP for treatment through the existing Process Equipment Waste (PEW) evaporator or the Liquid Effluent Treatment and Disposal (LET\&D) facility. Transporting the residues would require an estimated five transport vehicle round trips from TAN to ICPP and would be conducted in accordance with DOT requirements. The PEW condensate would be treated at the LET\&D to remove radionuclides and the treated effluent would be discharged to the atmosphere through the main LET\&D stack. The concentrates would be sent to the High Level Liquid Waste (HLLW) Tank Farm.

b) Transporting the entire volume of pool water to ICPP for treatment and disposal through the LET\&D and PEW, which would require an estimated 160 round trips from TAN to ICPP. Transportation would be conducted in compliance with DOT requirements. Residues from the treatment systems would be sent to the HLLW Tank Farm as discussed in (a).

c) Reducing the volume of pool water through an evaporative system at TAN, stabilizing the residuals by macro encapsulation or another suitable method, and disposing of the residuals in the RWMC as LLW.

d) Treating the water through an ion exchange or other suitable water treatment system at TAN, and discharging the treated water to (a) the TAN Technical Support Facility TSF-07 sewer system and associated pond or adjacent bermed water disposal area (Figure 6), (b) lined evaporation pond, or (c) directly to the land by a drip or sprinkler system.

\subsection{Alternatives to the Proposed Action}

This section describes the no action alternative and alternatives that were considered but dismissed from further consideration in this EA. These alternatives do not resolve issues associated with the need for action identified in Section 1.1.

\subsubsection{No Action}

The no action alternative is to continue storage of TMI core debris, commercial fuels, and hardware in the TAN Pool. The TAN Pool would remain operational. Regular surveillance, monitoring, and maintenance of the pool area and Hot Shop would continue. These activities may include: physical inspection; underwater video inspection to ensure no loss of structural containment or integrity; and routine analysis of pool water. The leak detection monitoring and corrosion inspection devices that have been installed to address some of the vulnerabilities discussed in Section 1.1 would remain operational. The TMI canisters and storage racks would require periodic requalification for continued underwater storage.

\subsubsection{Alternatives Considered and Dismissed}

\subsubsection{Refurbish the TAN Pool.}

The TMI core debris and commercial fuels would be removed from the pool and placed into temporary storage. The pool would be upgraded to meet current standards. Suitable temporary storage facilities for the fuels and core debris do not exist at the INEEL. Because the underwater design life of the TMI core debris canisters is 30 years, the integrity of the canisters would have to be reevaluated periodically. Continued storage in the TAN Pool would require the Hot Shop to remain operational.

\subsubsection{Construct New Wet Storage.}

Construction of a new wet (underwater) storage pool would not meet the terms of the Settlement Agreement that requires DOE-ID to move SNF out of wet storage by 2023 . In addition, wet storage facilities incur high construction and maintenance costs. 


\subsubsection{Store the TMI Canisters and LOFT and Commercial Fuels in Existing ICPP Storage Systems.}

This alternative would transport the TMI core debris and commercial fuels from TAN to ICPP, then transfer them to either underground dry vault storage (CPP-749) or the Irradiated Fuel Storage facility (IFSF) located at CPP-603 (Figure 4). This alternative was eliminated from further evaluation because there is insufficient vault space and there are other INEEL fuels identified for storage in these vaults.

The IFSF is a shielded storage facility at ICPP and has 636 positions for canisters of SNF. There are currently 327 unused canister positions. The IFSF storage canisters are approximately $11-\mathrm{ft}$ tall and 18 inches in diameter while the TMI canisters are approximately 12.5 -ft tall and would extend approximately 18 inches above the IFSF vaults. There is not adequate space in the IFSF to transfer the TMI canisters into the IFSF canisters or for the necessary lifting and handling fixtures and tools. In addition, the TMI canisters are too tall for the shuttle bin, which transfers canisters from the handling cave to the storage area.

\subsubsection{Construct an ISFSI at TAN.}

Construction of an ISFSI at TAN for the TMI and commercial fuel does not reflect the decision to consolidate SNF storage at ICPP as decided in the Record of Decision for the SNF EIS (DOE 1995a). This alternative was included in the May, 1995 version of this EA and was subsequently eliminated.

\subsubsection{Construct an ISFSI at a Point Removed from above the Snake River Plain Aquifer.}

Paragraph E8 of the Settlement Agreement among DOE, the Department of the Navy and the State of Idaho (DOE 1995b) requires that DOE shall, after consultation with the State of Idaho, determine the location of dry storage facilities within the INEEL, which shall, to the extent technically feasible, be at a point removed from above the Snake River Plain Aquifer, an EPA designated sole source aquifer. In accordance with this Agreement, a review was conducted to determine if there is such an alternative site on the INEEL for the proposed ISFSI.

Figure 7 shows the boundaries of the INEEL imposed over a map of the Eastern Snake River Basin and the Eastern Snake River Plain Aquifer. There are two locations on the INEEL, the Birch Creek Area, and the Lemhi Range Area, that are not over the Snake River Plain Aquifer, but are still within the Eastern Snake River Basin or streamflow source area. These sites were also dismissed as one is near a geologic fault that could be considered a potential seismic threat. The other site was dismissed due to the parcel's proximity ( 1 mile) from a capable geological fault, steep slopes of the land, potential habitat for sensitive species, proximity to private land, and visibility from highway 22.

All precipitation that falls in the Eastern Snake River Basin that does not evaporate or is not transpired is transported by rivers and streams or flows underground to the Snake River Plain Aquifer. The Birch Creek Area is located over an alluvial aquifer that provides recharge to the Snake River Plain Aquifer. The Lemhi Range Area encompasses the southern extension of the Lemhi Mountain Range which contains many intermittent stream channels that drain to the Snake River Plain Aquifer. Neither area would provide a construction site for the proposed ISFSI that is hydrologically isolated from the Snake River Plain Aquifer. Additionally, the development of either the Birch Creek or the Lemhi Range areas would require site preparation in undeveloped locations, access road construction and the extension of utility lines, all of which would cause environmental impacts. The negative environmental impacts and the cost of developing separate infrastructure in either the Birch Creek or Lemhi Range area would be much greater than the construction of an ISFSI within the boundaries of an existing facility such as TAN or ICPP. For these reasons, the alternative of sighting the proposed ISFSI off the aquifer was eliminated from further consideration. 


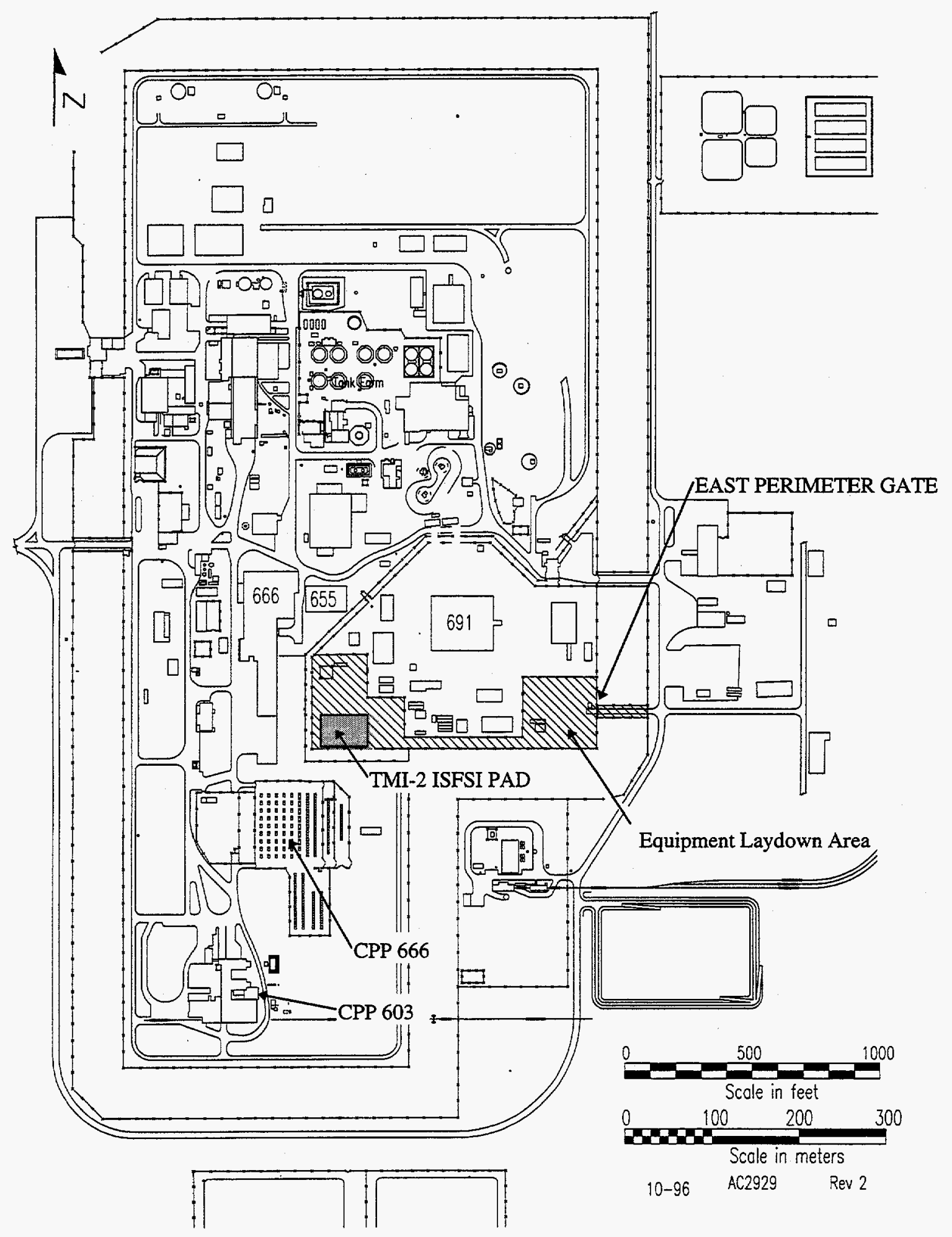

Figure 4 Proposed ISFSI location at ICPP 


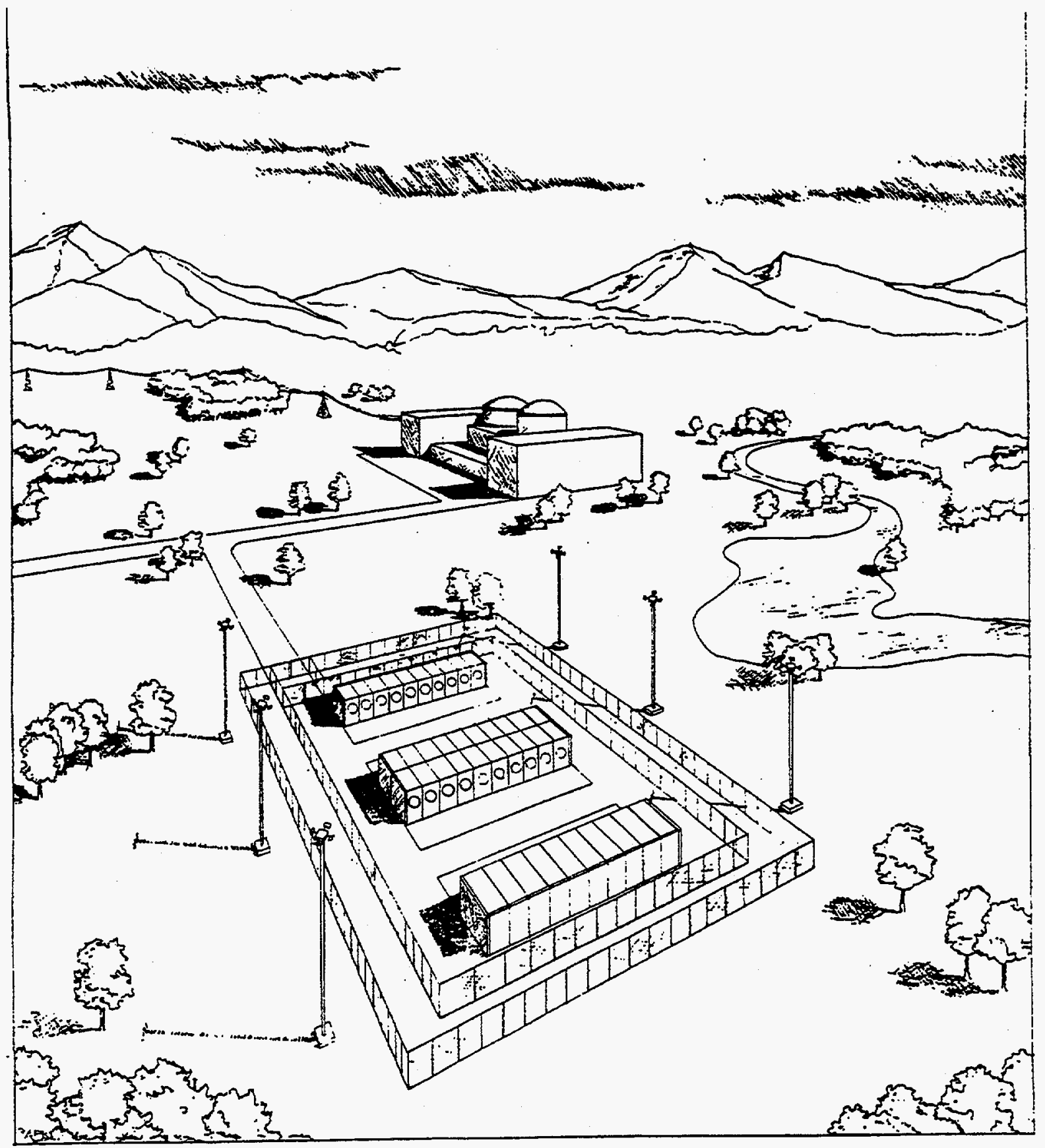

Figure 4a Artist Rendering of an ISFSI 


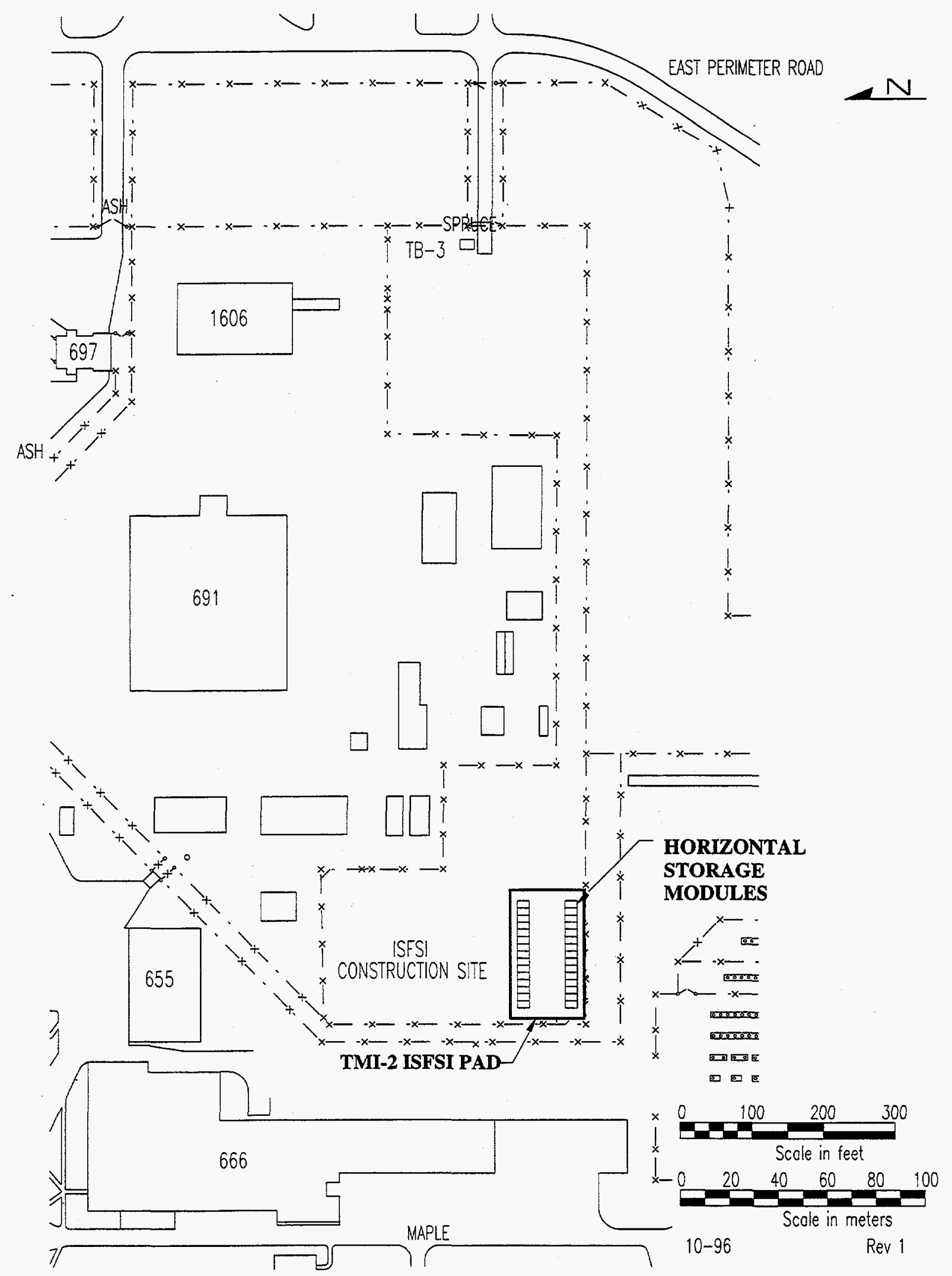

Figure 5 ISFSI Construction Site, TMI-2 ISFSI Pad and Storage Modules at ICPP. 


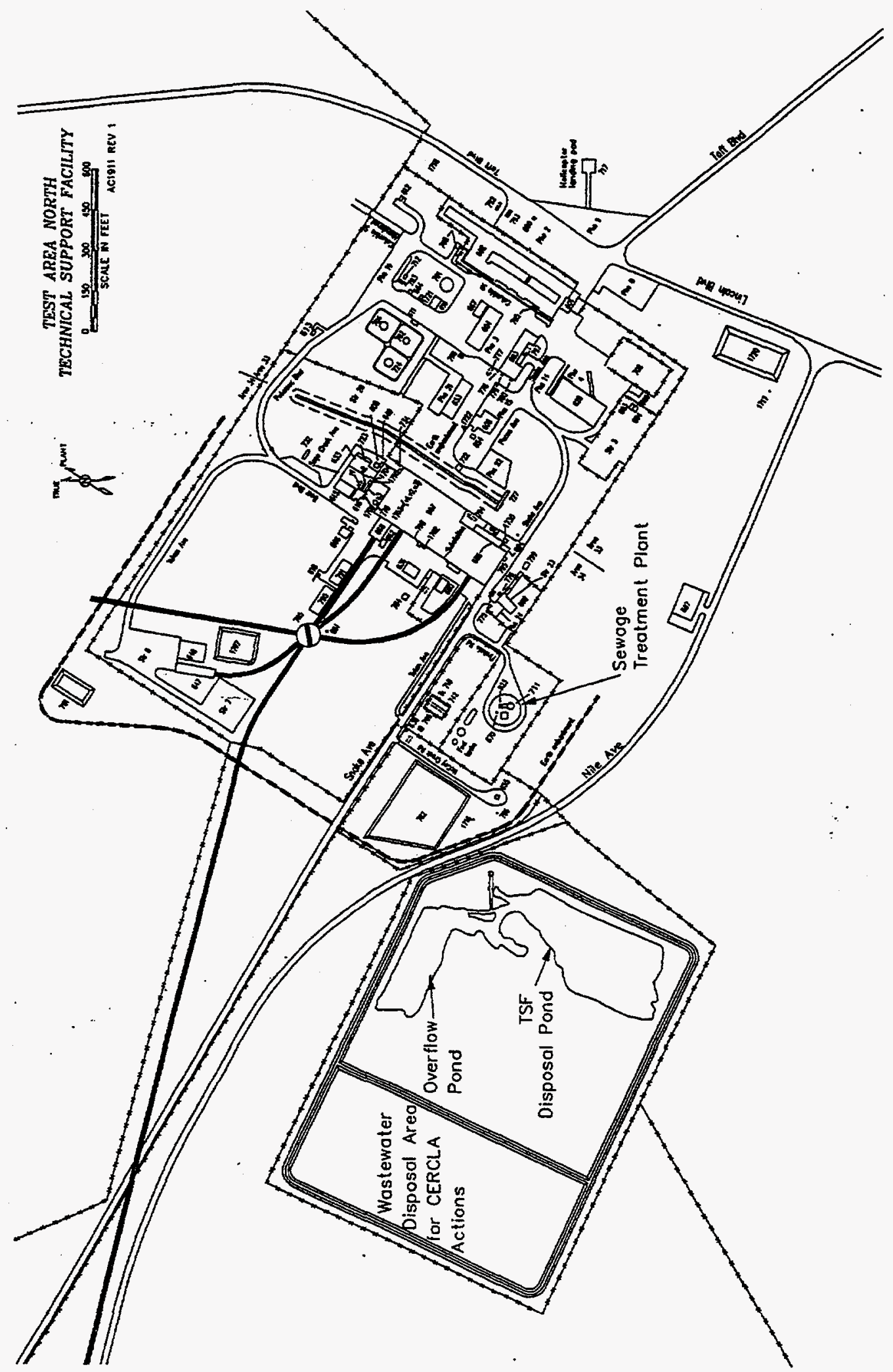

Figure 6 Location of TSF-07 Disposal Pond at TAN 


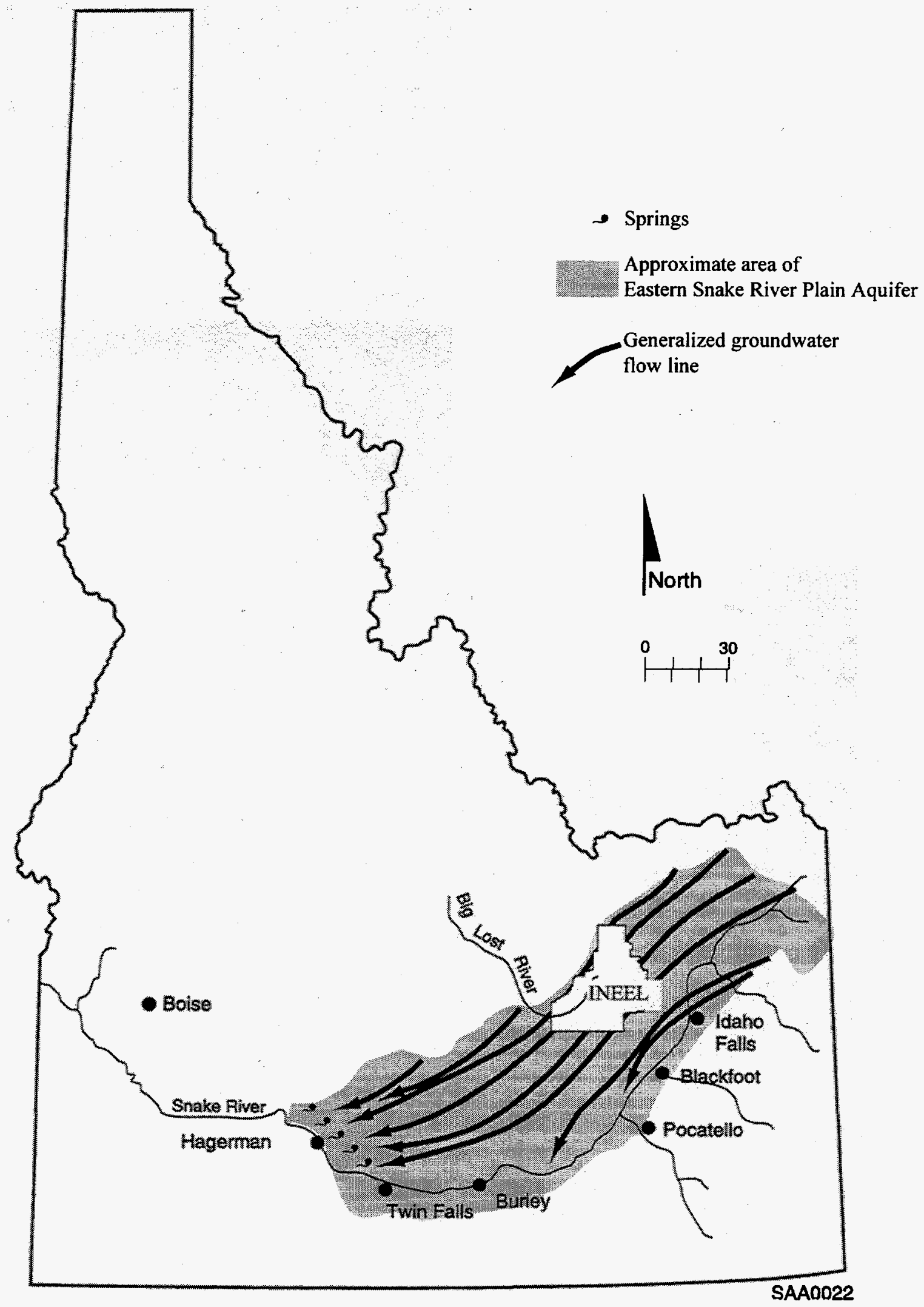

Figure 7 Location of the INEEL, Eastern Snake River Plain and the generalized flow direction of the Snake River Plain Aquifer (DOE 1995) 


\section{AFFECTED ENVIRONMENT}

The proposed action and alternatives would occur at ICPP and TAN, which are existing, developed facilities within the boundaries of the INEEL. The INEEL has been withdrawn from the public domain for the purpose of nuclear research and reactor testing. The INEEL occupies 890 square miles in southeastern Idaho on the Eastern Snake River Plain. Public highways U.S. 20 and 26 and Idaho 22, 28, and 33 pass through INEEL but off highway travel within the INEEL and access to INEEL facilities is controlled. A National Historic Landmark, Experimental Breeder Reactor-I, is located on the INEEL and is open to the public. For an extensive description of the INEEL's existing environment, please refer to the SNF EIS (DOE 1995). The SNF EIS conducted an extensive review of the INEEL's affected environment and, in lieu of duplicating this discussion in this EA, the applicable SNF EIS sections are provided in Table 1. It should be noted that since the SNF EIS was published in April 1995, the gray wolf has been listed by the U.S. Fish \& Wildlife Service as endangered; experimental/non-essential (USFWS 1995). The gray wolf may range on or near the INEEL.

Table 1. Resource and SNF EIS (DOE 1995) Cross Reference

\begin{tabular}{ll}
\multicolumn{1}{c}{ Resource } & SNF EIS Reference (DOE 1995) \\
General Site Description & Volumes 1 and 2, Section 4.1 \\
Land Use & Volumes 1 and 2, Section 4.2 \\
Socioeconomics & Volumes 1 and 2, Section 4.3 \\
Cultural Resources & Volumes 1 and 2, Section 4.4 \\
Aesthetic and Scenic Resources & Volumes 1 and 2, Section 4.5 \\
Site/Region Geologic Characteristics and & Volumes 1 and 2, Section 4.6 Volume 2, App. F-2 \\
Seismic Analysis & \\
Air Resources, Climate, and Meteorology & Volumes 1 and 2, Section 4.7 \\
Water Resources, Floodplain & Volumes 1 and 2, Section $4.8 ;$ Volume 2, Appendix F-2.2 \\
Ecological Resources & Volumes 1 and 2, Section 4.9 \\
Noise & Volumes 1 and 2, Section 4.10 \\
Traffic and Transportation & Volumes 1 and 2, Section 4.11 \\
Health and Safety & Volumes 1 and 2, Section 4.12 \\
INEEL Services & Volumes 1 and 2, Section 4.13 \\
\hline
\end{tabular}

The INEEL is located on the Eastern Snake River Plain, hereafter called the Plain. The surface of the Plain is comprised of sediments and basaltic lava flows. The lava flows range in age from 2,100 to 1.2 million years in the vicinity of the INEEL. The youngest flows on the INEEL have been dated at about 13,400 years. The Plain has historically experienced few and small earthquakes and geologic evidence suggests that moderate earthquakes (magnitude 5.5 or less) at the INEEL may have resulted from volcanic activity that ended 13,400 years ago. Basin and Range faulting adjacent to the plain has resulted in a higher rate of seismicity that can produce moderate to strong ground shaking at the INEEL. Seismic hazards at the INEEL include surface deformation (surface faulting, tilting) and ground shaking. Other potential seismic hazards (e.g., avalanches, landslides, mudslides, soil settlement, and soil liquefaction) are not likely to occur at the INEEL because the local geologic conditions are not conducive to them (DOE 1995). The magnitude and frequency of these potential seismic events and their surface accelerations at the INEEL have been quantitatively described in deterministic and probabilistic seismic hazard assessments for the ICPP and other INEEL facilities. The ISFSI would be designed to meet the NRC seismic requirements of 10 CFR 72 Licensing Requirements for the Independent Storage of Spent Nuclear Fuel and High-level Radioactive Waste. 
There are no permanent residents on the INEEL. ICPP is located 8 mi north of the INEEL's southern boundary. The town nearest ICPP is Atomic City located approximately $13 \mathrm{mi}$ to the southeast with a population of 25 . The town nearest TAN is Mud Lake, located approximately 15 mi to the east with a population of 170. The total INEEL work force in December 1995 was 8,294 and the number of employees at TAN and ICPP were 340 and 1,163 (respectively).

The areas within the fenced boundaries of ICPP and TAN have been surveyed for archaeological resources (Ringe 1993, and Reed et al. 1986). Both areas have been cleared in conjunction with earlier construction activities and no sites of archaeological or cultural importance were recorded.

Radiation in southeast Idaho in the vicinity of the INEEL consists of natural background radiation from cosmic, terrestrial, and internal body sources; manmade nuclear fallout; and radiation from consumer and industrial products. These sources result in an estimated total effective dose equivalent (EDE) of 350 millirem/year (mrem/yr) to an average member of the public residing in southeastern Idaho (DOE 1993b). In 1995, the INEEL added 1.80 E-02 mrem to the total background EDE ${ }^{c}$ (DOE 1996b). Doses were evaluated for historical releases from INEEL operations (DOE 1991a) and a hypothetical offsite resident near the INEEL boundary received an average dose of 5.4E-02 mrem/yr above background from 1980 to 1989.

Surface water flows on the INEEL consist of three intermittent streams (Big Lost River, Little Lost River, and Birch Creek) and localized runoff. The INEEL is located in a closed basin and no surface waters flow from the site. The Snake River Plain Aquifer is the principal groundwater feature in southeastern Idaho, underlying nearly all of the Plain. The Snake River Plain Aquifer was designated a sole source aquifer by the Environmental Protection Agency. Aquifer depths within the INEEL range from 200 to $900 \mathrm{ft}$. The depth to the aquifer at ICPP is approximately $450 \mathrm{ft}$ and perched water has been found in the unsaturated zone beneath ICPP at depths ranging from 40 to $377 \mathrm{ft}$. At TAN, the depth to the aquifer ranges from approximately $200 \mathrm{ft}$ to over $350 \mathrm{ft}$.

There are no wetlands or 100 year floodplains located within the ICPP that would impact (or be impacted by) the action. The combination of local climate, relief, and geology provides the INEEL with good natural flood-regulating characteristics. The Big Lost River is the only drainage to the INEEL that provides any real flood threat to the ICPP. A flood diversion system near RWMC, constructed in 1958 and enlarged in 1984, protects INEEL facilities such as ICPP from floods by diverting the floodwater to a basin that provides floodwater storage and infiltration. Based on an evaluation of the balance of storage and infiltration, the flood diversion system has the capability to accommodate the flood crest from the postulated 300-year flood (LITCO 1995a). The diversion system, therefore, is considered to provide adequate flood protection to the ICPP (LITCO 1995a) and the proposed ISFSI site. There are no siting limitations at the ICPP based on the 300 year floodplain, thus, the ISFSI is not anticipated to be affected. Snowmelt runoff on the INEEL normally occurs January through March, while runoff from the surrounding mountains generally occurs in May or June. If the ground is frozen when snowmelt occurs, flooding can result because the infiltration capacity of soil is greatly reduced. In 1969 TAN experienced snow melt flooding caused by heavy rains and warm winds (Bishop 1993). The construction of dikes at TAN have controlled this source of flooding.

The 500 year floodplain contour required by 10 CFR 1022 (Compliance With Floodplain/Wetlands Environmental Review Requirements) for critical actions has not been identified. However, the impact to the ICPP of a maximum probable flood (MPF) was analyzed to provide a conservative flooding

\footnotetext{
c. To convert a number from scientific notation to its original form, multiply the base number times 10 raised to the given exponent. For example: to convert $3 \mathrm{E}-06$, multiply $3 \times 10^{-6}$, giving 0.000003 or $3 / 1$ million.
} 
condition. The MPF is considered conservative as the last flood of the magnitude of an MPF occurred about 12,000 years ago during a wet climate cycle. The MPF scenario estimated flows at 35,000 cubic feet per second (cfs) with a water velocity that would range from 0.6 to 3.0 feet per second on the INEEL. This flood would result in shallow, slow-moving flood water within the ICPP-controlled area up to an elevation of $4916.6 \mathrm{ft}$. Based on elevations at ICPP, facilities that are in the northern half of the ICPP area would have approximately one to two feet of water while the southern end of ICPP would be above the MPF elevation (LITCO 1995a). Due to spreading and the resulting low velocity and shallow depth of the water, flooding would not pose a threat of structural damage to ICPP or TAN facilities (DOE 1995). 


\section{ENVIRONMENTAL IMPACTS}

\subsection{Impacts Associated with the Proposed Action}

\subsubsection{Construction Impacts}

Impacts associated with construction of the proposed ISFSI at ICPP would be confined to approximately one acre of previously disturbed, undeveloped area. If contaminated soil is encountered during construction, the soil would be handled in accordance with INEEL procedures. Radiological Control Technicians would be on duty to monitor excavation activities. Gravel used for fill material would be obtained from existing INEEL borrow pits.

Excavation and leveling activities associated with construction would generate temporary local particulate atmospheric pollution in the form of dust and vehicular emissions. Dust suspension would be controlled with water sprays or other soil fixatives as necessary. Equipment for construction of the ISFSI would also produce a short-term increase in noise.

Nonradioactive solid waste generated from construction activities would be less than $300 \mathrm{ft}^{3}$ and would be disposed of in the existing INEEL landfill. This would be less than $1 \%$ of the total volume of waste disposed of annually in the INEEL landfill complex. The landfill complex is expected to provide adequate solid waste disposal capacity for the INEEL for the next 30 to 50 years (DOE 1995).

Archaeological resources are not expected to be encountered during construction. However, the INEEL Cultural Resource Management Office would be consulted to assess the significance of artifacts should any be detected during construction. The INEEL Cultural Resource Management Office would consult with the State Historic Preservation Officer (SHPO) and the Shoshone-Bannock Tribe, as necessary, to ensure appropriate follow-on actions. The National Historic Preservation Act (NHPA) of 1966 (See Section 5.0) requires agencies to consider the impact of activities on properties listed or eligible for listing in the National Register of Historic Places (36 CFR 800). The TAN Pool and Hot Shop are potentially eligible for this listing. There would be minimal impacts to the INEEL's ecology because all construction impacts would be contained within the fenced boundaries of ICPP.

Groundwater at ICPP would not be affected by construction activities resulting from the proposed action. The construction would be conducted in accordance with requirements for storage and use of chemicals and construction materials so as to prevent potential contamination of the groundwater. The Siting Analysis Summary for the TMI Debris and Commercial Fuel Interim Storage System (Appendix B of DOE 1996a) also considered site suitability associated with factors such as adjacent ICPP land use, expansion capability, socioeconomics, aesthetics, access, transportation, utility (services) limitations, and impacts from adjoining facilities, and determined that there would be minimal adverse impacts associated with the proposed action.

\subsubsection{Operational Impacts}

\subsubsection{Impacts to Air Quality .}

Existing TAN Pool Storage

The existing storage configuration of the TMI- 2 core debris allows the emission of gaseous products generated from radiolysis of water within the canisters. The nature of the vent tubes (long, small diameter, water-filled) prevents emissions of any radionuclides in particulate form to the air above the TAN Pool. The pool air can enter the atmosphere via open doors, windows, and other diffusion processes. The existing configuration of the commercial fuel storage is not believed to contribute to a release of radionuclides because there is no mechanism for particulate matter resuspension or emission to the atmosphere in their current configuration. 
Potential Emissions and Effective Dose Equivalent (EDE) to the Maximally Exposed Individual (MEI)

Potential radionuclide emissions from the proposed action were calculated in an analysis of the canister dewatering and drying at TAN and dry storage at ICPP (See Table 2). The CAP-88 computer code (EPA 1990), an EPA approved method of modeling radionuclide emissions, was used to calculate Effective Dose Equivalent (EDE) to the Maximally Exposed Individual (MEI) from the activities. The EDE includes the 50-year Committed EDE from internal exposure through the ingestion and inhalation pathways and the external EDE from ground deposition and air immersion. The calculated EDE to the MEI is listed in Table 3. The EDE is a conservative estimate as the MEI location, for purposes of this calculation, is identified as a person living at the INEEL boundary. Potential emissions resulting from the activities would be evaluated as identified in Section 5.0 and monitored as required. The estimated doses to the MEI from the proposed action and the no action alternative (continued storage) are well below the NESHAP limit of $10 \mathrm{mrem} / \mathrm{yr}$.

Table 2. Potential Radionuclide Inventory and Releases (Staley, 1996) (Staley, 1997)

\begin{tabular}{|l|l|l|l|l|}
\hline Nuclide & $\mathbf{C i}$ in fuel & $\begin{array}{l}\text { Current TAN pool } \\
\text { storage release } \\
(\mathbf{C i} / \mathbf{y r})\end{array}$ & $\begin{array}{l}\text { Dewatering and } \\
\text { Drying Release }(\mathrm{Ci} / \mathbf{y r})\end{array}$ & $\begin{array}{l}\text { ICPP storage Release } \\
(\mathbf{C i} / \mathbf{y r})\end{array}$ \\
\hline $\mathrm{H}-3$ & $7.80 \mathrm{E}+02$ & $7.80 \mathrm{E}+01$ & $7.80 \mathrm{E}+01$ & $7.80 \mathrm{E}+01$ \\
\hline $\mathrm{Co}-60$ & $1.13 \mathrm{E}+04$ & $3.89 \mathrm{E}-06$ & $6.78 \mathrm{E}-12$ & $6.63 \mathrm{E}-06$ \\
\hline $\mathrm{Kr}-85$ & $1.52 \mathrm{E}+04$ & $1.52 \mathrm{E}+03$ & $1.52 \mathrm{E}+03$ & $1.52 \mathrm{E}+03$ \\
\hline $\mathrm{Sr}-90$ & $2.43 \mathrm{E}+05$ & $8.36 \mathrm{E}-05$ & $1.46 \mathrm{E}-10$ & $1.43 \mathrm{E}-04$ \\
\hline $\mathrm{Y}-90$ & $2.43 \mathrm{E}+05$ & $8.36 \mathrm{E}-05$ & $1.46 \mathrm{E}-10$ & $1.43 \mathrm{E}-04$ \\
\hline $\mathrm{I}-129$ & $1.14 \mathrm{E}-01$ & $1.14 \mathrm{E}-02$ & $1.14 \mathrm{E}-02$ & $1.14 \mathrm{E}-02$ \\
\hline $\mathrm{Cs}-134$ & $2.34 \mathrm{E}+02$ & $1.03 \mathrm{E}-07$ & $1.40 \mathrm{E}-13$ & $1.37 \mathrm{E}-07$ \\
\hline $\mathrm{Cs}-137$ & $2.85 \mathrm{E}+05$ & $1.10 \mathrm{E}-04$ & $1.71 \mathrm{E}-10$ & $1.67 \mathrm{E}-04$ \\
\hline $\mathrm{Ba}-137 \mathrm{~m}$ & $2.70 \mathrm{E}+05$ & $1.05 \mathrm{E}-04$ & $1.62 \mathrm{E}-10$ & $1.58 \mathrm{E}-04$ \\
\hline $\mathrm{Eu}-154$ & $2.29 \mathrm{E}+03$ & $7.87 \mathrm{E}-07$ & $1.37 \mathrm{E}-12$ & $1.34 \mathrm{E}-06$ \\
\hline $\mathrm{Pu}-238$ & $9.48 \mathrm{E}+02$ & $3.26 \mathrm{E}-07$ & $5.69 \mathrm{E}-13$ & $5.56 \mathrm{E}-07$ \\
\hline $\mathrm{Pu}-239$ & $9.34 \mathrm{E}+03$ & $3.21 \mathrm{E}-06$ & $5.60 \mathrm{E}-12$ & $5.48 \mathrm{E}-06$ \\
\hline $\mathrm{Pu}-240$ & $2.86 \mathrm{E}+03$ & $9.83 \mathrm{E}-07$ & $1.72 \mathrm{E}-12$ & $1.68 \mathrm{E}-06$ \\
\hline $\mathrm{Pu}-241$ & $1.03 \mathrm{E}+05$ & $3.54 \mathrm{E}-05$ & $6.18 \mathrm{E}-11$ & $6.04 \mathrm{E}-05$ \\
\hline $\mathrm{Am}-241$ & $4.67 \mathrm{E}+03$ & $1.61 \mathrm{E}-06$ & $2.80 \mathrm{E}-12$ & $2.74 \mathrm{E}-06$ \\
\hline
\end{tabular}

${ }^{1}$ Radionuclide inventory of 1984 TMI debris is decayed to 1997. 
Table 3. EDE to MEI Due to Potential Airborne Releases - Existing Storage and Proposed Action (Christensen 1997, Staley 1996, Staley 1997).

\begin{tabular}{|l|l|}
\hline \multicolumn{1}{|c|}{ Activity } & \multicolumn{1}{c|}{ EDE to MEI $^{1}$} \\
\hline Existing TAN Storage Pool & $3.2 \mathrm{E}-03 \mathrm{mrem} / \mathrm{yr}$ \\
\hline Proposed Dewatering and Drying Activity & $5.3 \mathrm{E}-03 \mathrm{mrem} / \mathrm{yr}$ \\
\hline Transport and Cask Receiving & $0.0 \mathrm{mrem} / \mathrm{yr}^{2}$ \\
\hline Proposed ICPP ISFSI Dry Storage & $2.7 \mathrm{E}-03 \mathrm{mrem} / \mathrm{yr}$ \\
\hline
\end{tabular}

${ }^{1}$ All doses modeled with CAP-88 computer code using releases from Table 2 . Five-year average (1987-91) meteorological data from TAN and Grid 3 met towers used for TAN and ICPP, respectively. MEIs located at: 1) 12,100 meters NNE of TAN for TAN releases; and 2) 13,800 meters SW of ICPP for ICPP releases.

${ }^{2}$ Canisters sealed during this time.

\section{Emissions from Pool Water Treatment and Discharge}

Water treatment and discharge activities would not increase the total amount of radionuclide emissions from the INEEL. There would be no radionuclide emissions from the ion-exchange treatment process because the system would be completely contained. The treatment system selected would be the best available technology that would remove the majority of the radionuclide constituents from the pool water. Although there is no known practicable method for removing tritium from liquid waste streams, the treatment and disposal operation would be designed and operated so that the tritium source and release would be considered in the ALARA (see Glossary) process. Discharging the treated water to an evaporation pond, land application, or an evaporative system, would release tritium to the atmosphere through evaporation of the discharged water. Worker exposures to tritium released by evaporation or volatilization from an unlined evaporation pond such as TSF-07, were modeled conservatively assuming the water would be discharged in the year 2001 and the entire volume of water would evaporate in one year. Exposure pathways were assumed to be inhalation and skin absorption. The dose to workers was determined to be $2.92 \times 10^{-3}$ mrem or $2.92 \times 10^{-6} \mathrm{rem}$, which is well below the worker dose limit of 2.0 rem/yr (Thorne 1995). Anticipated emissions of tritium (which has a half-life of 12.5 years) from the discharged water would result in doses that would cause no adverse health effects to the public.

Vehicular exhaust emissions would result from truck transport of pool water from TAN to ICPP. Approximately 50 round trips would be necessary to transport the TMI canisters and commercial fuel to ICPP and up to 160 round trips for transporting the pool water from TAN to ICPP (See section 2.1.3). Foreseeable impacts from vehicular exhaust emissions are evaluated in the SNF EIS (DOE 1995). The SNF EIS indicates that vehicular exhaust emissions under any alternative would be below the applicable air quality standards, and could be attributed almost entirely to general traffic conditions. Therefore, in comparison, exhaust emissions resulting from the proposed action would contribute an inconsequential increase in vehicular-induced air impacts (DOE 1995).

\subsubsection{Exposure to Radiation.}

TAN operations for TMI debris and commercial fuel removal, dewatering and loading would be conducted in accordance with DOE Orders. A radiological work permit would be required for activities that have a potential to expose workers, to ensure that work is conducted in a safe manner and that exposure would be kept ALARA. Worker doses would be monitored by dosimeters and the dose to a worker would not be allowed to exceed the applicable regulatory limits (10 CFR 835 and DOE 1995d). 
The transportation from TAN to ICPP would be conducted so as to minimize radiation exposure. Specific criteria to limit radiation exposure during transport (10 CFR 71.47) include:

200 mrem per hour on the accessible external surface of the canister

200 mrem per hour at any point on the outer surface of the vehicle

10 mrem per hour at any point 2 meters from the vertical planes represented by the outer lateral surfaces of the vehicle.

2 mrem per hour in any normally occupied part of the vehicle.

Radiation exposures from the ISFSI at ICPP (Table 3) are below the limits identified in 10 CFR 72.104. This provides that during normal operations and anticipated occurrences, the annual dose equivalent to any individual who is located beyond the controlled area must not exceed 25 mrem to the whole body, 75 mrem to the thyroid and 25 mrem to any other organ as a result of exposure.

\subsubsection{Waste Generation and Disposition.}

\subsection{Liquid Effluent}

Approximately 780,000 gal. of water would remain in the TAN Pool following removal of the fuel bearing materials and hardware from the pool. Spectroanalyses of the pool water conducted in 1991 and 1992 identified the following concentration of radionuclides: $3.038 \mathrm{E}-06 \mu \mathrm{Ci} / \mathrm{mL}$ of cobalt- $60(\mathrm{Co}-60)$, 7.7E-05 $\mu \mathrm{Ci} / \mathrm{mL} \mathrm{Cs}-137$, and $2.0 \mathrm{E}-05 \mu \mathrm{Ci} / \mathrm{mL}$ of tritium. Derived concentration guides (DCGs) for these radionuclides from DOE Order 5400.5 are 3.0E-06 $\mu \mathrm{Ci} / \mathrm{mL}$ for Cs-137 and 5.0E-06 $\mu \mathrm{Ci} / \mathrm{mL}$ for Co-60. The maximum contaminant level (MCL) for tritium in drinking water is $2.0 \mathrm{E}-03 \mu \mathrm{Ci} / \mathrm{mL}$.

Upon removal of the debris, fuel, and equipment, the pool water would be analyzed to determine the appropriate treatment technology. If the treated water would be disposed of in the TSF-07 pond or adjacent associated bermed area, or by land application, disposal would be in compliance with Federal and State discharge requirements (see Section 5.0). Air emissions associated with treatment and discharge of pool water to an evaporation pond or by an evaporative system would be evaluated and may require a PTC (see Section 5.0). Land application of the treated water would not have a negative impact on site ecology and may be used to irrigate vegetation and improve wildlife habitat.

\subsection{Solid Waste}

The TMI core debris, commercial fuels, and pool water are not RCRA regulated (LITCO 1995) and the proposed action is not anticipated to generate hazardous or mixed waste. However, if any hazardous or mixed waste is generated during dewatering operations or pool stabilization, the waste would be treated, stored, and disposed of in accordance with RCRA (40 CFR Parts 260-265) and the RCRA Land Disposal Restrictions (40 CFR Part 268).

The proposed action would generate nonradioactive and radioactive solid waste. An estimated $300 \mathrm{ft}^{3}$ of solid nonradioactive waste would be disposed of in the INEEL landfill complex. The estimated unconsolidated volume of solid nonincinerable radioactive waste generated would include $50 \mathrm{ft}^{3}$ of upper support structures removed from the LOFT fuel assemblies; $200 \mathrm{ft}^{3}$ of filters, removed particles, and resin beds from the water treatment system; and 17,000 $\mathrm{ft}^{3}$ of TMI six-pack storage modules and poison plates, LOFT storage containers, fuel storage coffins, and storage rack. This solid nonincinerable radioactive material that is LLW and would be sized (see Glossary) and disposed of at the RWMC. Radioactively contaminated incinerable solid wastes such as personal protective equipment would be sent to WERF for treatment. The INEEL Landfill Complex, RWMC, and WERF have sufficient capacity to accept the solid wastes generated by the proposed action in addition to other INEEL activities (DOE 
1995), and the wastes would be disposed of in accordance with the respective facility's waste acceptance criteria.

\subsubsection{Impacts On Socioeconomic Factors and Biological and Cultural Resources.}

The proposed action would not require a permanent increase in the number of INEEL employees. Activities at TAN associated with dewatering, preparation for transport, and pool stabilization would require an average of 10 workers over the project's life. ISFSI construction at ICPP would require an average of 20 construction workers on the site for approximately 1 year. Temporary increases in workers would have minimal impact on regional socioeconomics. The DOE operating contractor would be responsible for managing the ISFSI operations upon completion of construction activities.

The ISFSI site is within facility boundaries and has been cleared and graded in conjunction with previous construction activities. There is no unique or critical habitat involved and there would be no adverse impact to wildlife or vegetation or any listed threatened or endangered species. A biological assessment would not be required (Reynolds, 1993).

There would be no impacts to cultural resources resulting from the proposed action. No part of the proposed action would result in modification of the TAN 607 structure that would affect its eligibility for listing on the National Register of Historic Places.

\subsubsection{Potential Impacts from Accidents}

\subsubsection{Potential Handling Accidents.}

The accidents described in this Section provide the bounding accident analysis associated with handling of canisters and commercial fuel for the proposed action. These potential accident scenarios were initiated by an earthquake (with an occurrence frequency of once in 10,000 years) that would occur during dewatering and loading operations in the Hot Shop (Abbott 1992). These accident scenarios also provide the bounding accident scenario associated with drying activities. Conservative estimates of radionuclide releases (Table 4) and dose impacts (Table 5) were evaluated for:

- A single TMI canister drop during crane transfer within the Hot Shop.

- A single commercial fuel assembly drop during transfer within the Hot Shop.

The dose from the dropped TMI canister accident was calculated using a filter canister since these are the only ones that contain particles small enough to be aerosolized. The release fractions assumed for the dropped canister accident were 1.0 for $\mathrm{Kr}-85$ and $\mathrm{H}^{3}, 0.3$ for $\mathrm{I}-129$, and 0.01 for dispersible solids in the canister. For these calculations, $10 \%$ of the core debris in the filter canisters was assumed to be dispersible solids with a diameter less than 1.0E-09. The dose from the dropped commercial fuel assembly accident is based on calculations using a commercial reactor spent fuel assembly. The LOFT fuels have a much lower burnup than commercial fuel, which would actually result in smaller fission product inventories and, therefore, smaller potential releases of radionuclides (Peterson 1991). The impact from the assembly drop is assumed to rupture $100 \%$ of the fuel rod cladding but not crush the fuel matrix. The gaseous fission products present in the fuel-clad gap would be released, but there would be no releases of solid fission products because they are contained within the fuel matrix. The amounts of gaseous fission products in the commercial fuel assembly were calculated using the ORIGEN2 computer code (DOE 1987) and a 10-year decay period. The gaseous fission product inventory in the fuel assembly was calculated to be $195 \mathrm{Ci}$ of tritium, $0.634 \mathrm{Ci}$ of carbon-14, and 2,060 Ci of $\mathrm{Kr}-85$. Thirty percent of the total inventory in the assembly is assumed to be present in the fuel-clad gap and would be released (Table 5). 
The RSAC-4 code was used to model radionuclide air dispersion and environmental transport because it is a site-specific code with the capability to evaluate short-term accident releases. For the scenarios, it was conservatively assumed the Hot Shop ventilation and filtration system would fail and radionuclides would be released to the atmosphere at ground level. Worst-case dispersion conditions of stability class $F$ and a wind speed of two meters per second were assumed.

The handling accident involving a dropped commercial fuel assembly produced a calculated dose to the maximally exposed individual of $1.1 \mathrm{rem}$. This dose is about 6 times greater than the dose calculated for a dropped TMI canister. For the dropped fuel assembly accident, the probability of inducing a fatal cancer in the maximally exposed individual would be about one chance in 1,800 , so no adverse health effects to the MEI would be anticipated. The potential for an accident and associated dose consequences will be reduced by limiting access to the Hot Shop during operations, using remotely operated equipment, as practical, and controlling activities in accordance with written procedures.

An accident scenario based on a fuel assembly or TMI canister drop during transfer activities into an ISFSI at ICPP was not analyzed because a breach of a DOT approved SNF transport cask is incredible (a chance of less than 1 in a million) and the ISFSI would be designed to withstand a design basis seismic event or dropped storage canister.

Table 4. Upper-bound estimates of airborne radionuclides (curies/accident) resulting from postulated accidents of the proposed action during Hot Shop operations.

\begin{tabular}{|l|c|l|}
\hline \multicolumn{1}{|c|}{ Radionuclide } & $\begin{array}{c}\text { Dropped TMI canister } \\
\text { (Ci/accident) }\end{array}$ & $\begin{array}{c}\text { Dropped Commercial Fuel } \\
\text { assembly (Ci/accident) }\end{array}$ \\
\hline Tritium (H-3) & $2.80 \mathrm{E}+00$ & $5.85 \mathrm{E}+01$ \\
\hline Carbon (C-14) & - & $1.90 \mathrm{E}-01$ \\
\hline Krypton (Kr-85) & $5.73 \mathrm{E}+01$ & $6.17 \mathrm{E}+02$ \\
\hline Iodine (I-129) & $1.00 \mathrm{E}-04$ & 0 \\
\hline Cobalt (Co-60) & $1.08 \mathrm{E}-01$ & 0 \\
\hline Strontium (Sr-90) & $1.55 \mathrm{E}+00$ & 0 \\
\hline Ytrium (Y-90) & $1.55 \mathrm{E}+00$ & 0 \\
\hline Cesium (Cs-134) & $2.62 \mathrm{E}-03$ & 0 \\
\hline Cesium (Cs-137) & $9.01 \mathrm{E}-01$ & 0 \\
\hline Barium (Ba-137m) & $8.53 \mathrm{E}-01$ & 0 \\
\hline Europium (Eu-154) & $9.15 \mathrm{E}-03$ & 0 \\
\hline Plutonium (Pu-238) & $2.86 \mathrm{E}-03$ & 0 \\
\hline Plutonium (Pu-239) & $2.72 \mathrm{E}-02$ & 0 \\
\hline Plutonium (Pu-240) & $8.34 \mathrm{E}-03$ & 0 \\
\hline Plutonium (Pu-241) & $3.62 \mathrm{E}-01$ & 0 \\
\hline Americium (Am-241) & $1.16 \mathrm{E}-02$ & 0 \\
\hline
\end{tabular}

2. The dropped fuel assembly scenario assumes that the fuel rod cladding will be ruptured and that gaseous fission products in the fuel-clad gap will be released. The fuel matrix is not crushed, so there is no release of solid fission products. 
Table 5. Summary of radiological effects from releases under accident scenarios

\begin{tabular}{|c|c|c|c|c|c|}
\hline \multirow[b]{2}{*}{$\begin{array}{l}\text { Accident } \\
\text { Scenario }\end{array}$} & \multirow[b]{2}{*}{$\begin{array}{l}\text { Exposure } \\
\text { Pathway }\end{array}$} & \multicolumn{4}{|c|}{ Effective Dose Equivalent (rem) } \\
\hline & & $\begin{array}{l}\text { Hot Shop } \\
\text { Worker }\end{array}$ & $\begin{array}{c}\text { Onsite Worker } \\
\text { @ 100-m }\end{array}$ & $\begin{array}{c}\text { Onsite Worker } \\
\text { @ 300-m }\end{array}$ & $\begin{array}{l}\text { Maximally Exposed } \\
\text { Individual }^{\mathrm{a}}\end{array}$ \\
\hline \multirow{5}{*}{$\begin{array}{l}\text { TMI Canister } \\
\text { Drop }\end{array}$} & Inhalation & $0^{\mathrm{b}}$ & $3.8 \mathrm{E}-01$ & $3.7 \mathrm{E}-01$ & $5.1 \mathrm{E}-02$ \\
\hline & Ingestion & $0^{c}$ & -- & - & $1.2 \mathrm{E}-01$ \\
\hline & Ground Surface & & $3.1 E-03$ & $3.0 \mathrm{E}-03$ & 4.2E-04 \\
\hline & Immersion & & $8.7 \mathrm{E}-06$ & 8.5E-06 & $1.2 \mathrm{E}-06$ \\
\hline & TOTAL & $\mathbf{0}$ & 3.8E-01 & $3.7 \mathrm{E}-01$ & 1.7E-01 \\
\hline \multirow{6}{*}{$\begin{array}{l}\text { Commercial } \\
\text { Fuel Assembly } \\
\text { Drop }\end{array}$} & Inhalation & $0^{b}$ & $7.3 \mathrm{E}-05$ & $7.2 \mathrm{E}-05$ & $9.9 \mathrm{E}-06$ \\
\hline & Ingestion & $0^{\mathrm{c}}$ & - & -- & $1.1 \mathrm{E}+00$ \\
\hline & Ground Surface & & 0 & 0 & 0 \\
\hline & Immersion & & $1.3 \mathrm{E}-05$ & 1.3E-05 & 1.7E-06 \\
\hline & TOTAL & $\mathbf{0}$ & $8.6 \mathrm{E}-05$ & 8.4E-05 & $1.1 \mathrm{E}+00$ \\
\hline & \multicolumn{5}{|c|}{ Health effects (number) ${ }^{d}$} \\
\hline \multicolumn{2}{|c|}{ TMI Canister Drop } & $0^{6}$ & $1.52 \mathrm{E}-04$ & $1.48 \mathrm{E}-04$ & 8.5E-05 \\
\hline \multicolumn{2}{|c|}{$\begin{array}{l}\text { Commercial Fuel } \\
\text { Assembly Drop }\end{array}$} & $0^{\mathrm{b}}$ & $3.4 E-08$ & 3.7E-08 & $5.5 \mathrm{E}-04$ \\
\hline
\end{tabular}

a. Nearest Site Boundary (6.4 miles east-northeast of TAN)

b. Workers will not be present in Hot Shop during canister/fuel transfers.

c. Worker doses do not include the ingestion pathway as no agricultural products are produced on the INEEL.

d. Health effects are defined as the latent cancer fatalities. A conversion factor of $4 \mathrm{E}-04$ cancer fatalities/person-rem for worker exposure and 5E-04 cancer fatalities/person-rem for public exposure was used for this analysis (10 CFR 20, "Standards for Protection Against Radiation: Final Rule," May 21, 1991).

\subsubsection{Transportation Accidents.}

The SNF EIS (DOE 1995) analyzed transportation accidents associated with onsite SNF shipment. The SNF EIS analysis provides a "bounding" estimate of the annual probability of fatal cancers occurring in the local population due to a transportation accident. However, potential accident impacts associated with transportation of the TMI debris and commercial fuels would be lower than the SNF EIS bounding scenario. This is due to the nature of the material (See Section 1.2) and the rigorous mitigative measures for SNF transport (DOE 1995).

\subsubsection{Potential for Accidents During Storage.}

An ISFSI is designed to mitigate the effects of design basis accidents (see glossary) that could occur during storage. Design basis accidents account for human-caused events and the most severe natural phenomena reported for the site and surrounding area. Postulated accidents analyzed for an ISFSI include tornado winds and tornado generated missiles, design basis earthquake, design basis flood, accidental cask drop, lightening effects, fire, explosions, and other incidents.

Special ISFSI design features include using nonflammable materials, providing a horizontal storage module with walls and a roof of structural steel and reinforced concrete (approximately 2.5 feet thick ) to house a dry-shielded steel canister, and a passive ventilation system. Considering, the specific design requirements, for each accident condition, the design of the ISFSI would prevent loss of containment, shielding, or criticality control (LITCO 1995b, DOE 1996c). 


\subsubsection{Cumulative Impacts}

The radiological releases from current and future INEEL operations (DOE 1995) to the worker, MEI, and the population within 50 miles of the INEEL are identified in Table 6 . The incremental and cumulative 10 year dose (from 1995-2005) includes emissions associated with the TAN Pool Stabilization Project. Based on exposure for the cumulative 10 year dose, the risk to an INEEL worker at the location of highest dose from airborne radionuclide emissions would cause an estimated increased lifetime chance of developing fatal cancer of less than 1 in 500,000. The cumulative occupational radiation dose received by the entire INEEL workforce (about 10,000 workers) over the 10 years would result in less than 1 fatal cancer. For comparison, the natural lifetime incidence of fatal cancers in the same population from all other causes would be about 2,000 (DOE 1995). Radiological dose impacts to the MEI were conservatively summed to derive cumulative impacts, although the location of the MEI may be different for each source. This conservatism serves to establish the upper-bounding dose. Despite this conservatism, the dose to the MEI is low (Table 6) and would result in a fatal cancer risk for the MEI of less than 1 occurrence in 300,000 . The cumulative 10 year dose from all INEEL activities including this action from 1995 through 2005 would result in an increase of less than one fatal cancer in the population within fifty miles of the INEEL (DOE 1995). The natural lifetime incidence of fatal cancers in the same population from all other causes would be about 24,000 out of a population of 120,000 . Radiological releases resulting from the proposed action, present INEEL operations, and the future actions would not be expected to cause adverse health effects to workers, the MEI, or the general public.

Increases in nonradiological atmospheric pollutants would consist of temporary localized releases associated with construction of the storage system and vehicular emissions during transportation. These emissions would not measurably add to time-averaged ambient air concentrations of pollutants at the INEEL (DOE 1995).

Cumulative impacts associated with waste generation would be minimal. The INEEL Landfill Complex, RWMC, and WERF have sufficient capacity to accept the wastes generated by the proposed action in addition to other INEEL activities (DOE 1995). It is anticipated there would be no increase in the amount of hazardous or mixed wastes generated on the INEEL that would result from the proposed action.

Table 6. Radiological Air Emission Baseline and Ten-year Dose (DOE 1995).

\begin{tabular}{|c|c|c|c|}
\hline & $\begin{array}{l}\text { INEEL Baseline } \\
\text { Annual Dose }\end{array}$ & $\begin{array}{c}\text { Annual Incremental } \\
\text { Dose }^{\mathrm{a} b}\end{array}$ & $\begin{array}{c}\text { Cumulative } \\
\text { Ten year Dose }{ }^{\text {b b }}\end{array}$ \\
\hline $\begin{array}{l}\text { Site worker (maximally } \\
\text { exposed worker }{ }^{c} \text { ) }\end{array}$ & $.32 \mathrm{mrem}$ & .14 mrem & $4.6 \mathrm{mrem}$ \\
\hline $\begin{array}{l}\text { Offsite individual } \\
\text { (MEI) }\end{array}$ & .05 mrem & $.58 \mathrm{mrem}$ & 6.3 mrem \\
\hline $\begin{array}{l}\text { Population within } 50 \\
\text { miles }{ }^{d}\end{array}$ & .30 mrem & $2.60 \mathrm{mrem}$ & 29.0 mrem \\
\hline Natural Background & 350 mrem & & 3,500 mrem \\
\hline \multicolumn{4}{|c|}{$\begin{array}{l}\text { a. Includes the Pool Stabilization Project. } \\
\text { b. Based on implementation of projects in the SNF EIS (DOE 1995) from } 1995 \text { to } 2005 . \\
\text { c. The maximally exposed worker is located at the Test Reactor Area. } \\
\text { d. Cumulative radiation dose (person-rem) to the population within } 50 \text { miles of site facilities from } \\
\text { INEEL operations from } 1995 \text { to } 2005 \text {. }\end{array}$} \\
\hline
\end{tabular}


The work force for this project would be drawn from existing INEEL employees or commercial vendors contracted to design and construct the system. Changes in INEEL employment resulting from the proposed action would be within normal fluctuations in INEEL employment.

The proposed action would not contribute to cumulative impacts to biological resources. Activities associated with the proposed action would occur within the boundaries of existing facilities at the INEEL.

The construction and operation of an ISFSI would consume irretrievable amounts of electrical energy, fuel and miscellaneous chemicals and indefinitely commit concrete, metals, plastics, lumber, sand, and gravel and a fraction of the water used in construction (DOE 1995). The proposed action would occur within the boundaries of existing industrial facilities and transportation would occur over an existing road that is adequate to support cask transport. Scarce or strategic material would not be used for the construction of the ISFSI.

\subsection{Impacts Associated with the No Action Alternative}

Annual airborne radionuclide emissions from the entire TAN facility are estimated to be $0.12 \mathrm{Ci}$ (DOE 1995). Emissions from the TAN Pool and TAN-607 facility would not change as a result of the no action alternative.

There is no evidence of deterioration of concrete in the TAN Pool. Data from the leak detection system indicates that there is no evidence of any water leakage. A seismic evaluation of the TAN Pool vestibule (Lacey 1994) determined the vestibule would prove adequate for a design basis (see Glossary) earthquake. The analysis found that the vestibule would withstand an earthquake having a peak spectral acceleration of about $0.43 \mathrm{~g}$ with no damage or leaks. For comparison, a maximum horizontal ground surface acceleration of $0.24 \mathrm{~g}$ at the INEEL is estimated to result from an earthquake that could occur once every 2,000 years (DOE 1995). While no seismic evaluations of the pool have been performed, the pool is similar in construction to the vestibule. Therefore, it may be inferred that a design basis earthquake will not result in cracking or leaking of the TAN Pool.

An event causing the water in the pool to drain, all mitigation responses to be ineffective (emergency water replacement systems unable to maintain water above the TMI canisters), and radiation sources in the pool to be exposed was analyzed (Rohrig, 1991). Resultant radiation levels at $6.6 \mathrm{ft}$ above the empty pool ranged from 1.5 to $7 \mathrm{rad} / \mathrm{hr}$ at the pool edge and 13 to $45 \mathrm{mrad} / \mathrm{hr}$ at $82 \mathrm{ft}$ away from the edge of the pool. Radiation entering the Hot Shop from the pool was not a concern as there are administrative and evacuation measures that require workers to leave the Hot Shop if an incident occurs.

Although the TAN Pool, in its current condition, poses minimal threat to human health and the environment, the no action alternative would not ensure compliance with the Settlement Agreement (DOE 1995b). The TAN Pool ventilation system is not adequate and there is no secondary containment system for the TAN Pool water. Continued use of the pool storage could require extensive modifications to meet environmental and safety requirements. Additionally, storage of the TMI core debris in the TAN Pool would require continuing maintenance of the Hot Shop and pool until the ultimate storage location or disposition of the TMI core debris is determined. 


\section{PERMIT AND REGULATORY REQUIREMENTS}

Prior to project implementation, an air emission evaluation would be conducted to determine air permitting requirements (IDAPA 1996a) applicable to the project. A PTC, if required, would address potential emissions associated with the fuel and debris removal from the TAN Pool and the operation of the ISFSI. Following removal of the commercial fuel, debris and hardware from the pool, an air evaluation of the pool water treatment and disposal process would be conducted and required air permits would be obtained.

The Siting Analysis Summary for the TMI Debris and Commercial Fuel Interim Storage System (Appendix B of DOE 1996a) identified that the ISFSI site is not in a RCRA, CERCLA, or radiologically controlled area. During site investigation, preparation, and construction at ICPP, the activities would be monitored to ensure ongoing compliance with RCRA, CERCLA, and radiological control requirements and ensure proper management of environmental media such as soils.

Radionuclide emissions from DOE facilities are regulated under the 40 CFR Part 61, NESHAP, at Subpart H and IDAPA (IDAPA 1996a). The regulations require a NESHAP permit to construct (PTC) approval if the modeled unmitigated EDE to a MEI is above $1 \%$ of the $10 \mathrm{mrem} / \mathrm{yr}$ standard $(0.1$ $\mathrm{mrem} / \mathrm{yr}$ ). A permit to construct applicability determination was submitted to the Idaho Department of Health and Welfare, Division of Environmental Quality (DEQ) for the proposed ISFSI installation at ICPP (Mitchell 1997). The potential EDE to the MEI for ICPP dry storage was calculated to be 2.4 E-02 and $5.9 \mathrm{E}-03 \mathrm{mrem} / \mathrm{yr}$ for NESHAP permitting and best engineering estimate, respectively. Based on these calculations, it is anticipated that a NESHAPs PTC would not be required for the ISFSI.

The NESHAP evaluation of the dewatering and drying operations at TAN (Staley, 1997) calculates the potential EDE to the MEI to be $5.9 \mathrm{E}+04,5.9 \mathrm{E}-01$, and 5.3E-03 mrem/yr for NESHAP permitting, NESHAP monitoring, and best engineering estimate, respectively. Based on this information, it is anticipated that a NESHAPs application to construct and stack monitoring would be required for dewatering and drying activities at Test Area North.

Surface land application of the treated pool water could require an Idaho Wastewater Land Application Permit in accordance with the Idaho Wastewater Land Application Permit Requirements (IDAPA 1996b). Surface land application of the pool water would require treatment to meet the release criteria, as defined by State or Federal requirements at the time of treatment, for discharge of liquid effluent with radionuclides. Discharges would also be required to meet DOE Order 5400.5 (DOE 1993c) and 10 CFR 835.

A stormwater pollution prevention plan would be completed before construction of the ISFSI at ICPP. The plan would be prepared in accordance with the INEEL Stormwater Pollution Prevention Plan (DOE 1993d) and the regulations for "National Pollutant Discharge Elimination System (NPDES) General Permit for Stormwater Discharges Associated with Construction Sites" (40 CFR 122 et. seq.) The purpose of a storm water pollution prevention plan is to prevent erosion products and sediment from running off the site during construction. 
Following are the major laws, regulations and other requirements that are applicable to the proposed action analyzed in this EA. Detailed summaries of these laws can be found in the Volume 1, Chapter 7 of the SNF EIS (DOE 1995) which is incorporated by reference.

- National Environmental Policy Act of 1969, as amended (42 USC $\$ 4321$ et seq.)

- Atomic Energy Act of 1954, as amended (42 USC \$2011 et seq.)

- Nuclear Waste Policy Act of 1982, as amended, (42 USC §10101-10270).

- Clean Air Act, as amended (42 USC $\$ 7401$ et seq.)

- Safe Drinking Water Act, as amended (42 USC $\S 300\{F\}$ et seq.)

- Clean Water Act, as amended (33 USC §1251 et seq.)

- Resource Conservation and Recovery Act, as amended (42 USC $\$ 6901$ et seq.)

- Comprehensive Environmental Response, Compensation, and Liability Act, as amended (42 USC $\$ 9601$ et seq.)

- Emergency Planning and Community Right-to-Know Act of 1986 (also known as "SARA Title III") (42 USC $\$ 11001$ et seq.).

- Toxic Substances Control Act (15 USC $\$ 2601$ et seq.)

- Pollution Prevention Act of 1990 (42 USC $\$ 13101$ et seq.)

- Federal Facility Compliance Act (42 USC $\$ 6921$ et seq.)

- National Historic Preservation Act, as amended (16 USC $\$ 470$ et seq.)

- Archaeological Resource Protection Act, as amended (16 USC $\$ 470$ aa et seq.)

- Native American Grave Protection and Repatriation Act of 1990 (25 USC §3001).

- American Indian Religious Freedom Act of 1978 (42 USC \$1996).

- Religious Freedom Restoration Act of 1993 (42 USC $\$ 2000$ bb et seq.)

- Endangered Species Act, as amended (16 USC $\$ 1531$ et seq.)

- Migratory Bird Treaty Act, as amended (16 USC $\$ 703$ et seq.)

- Bald and Golden Eagle Protection Act, as amended (16 USC §668-668d).

- Occupational Safety and Health Act of 1970, as amended (29 USC $\$ 651$ et seq.)

- Noise Control Act of 1972, as amended (42 USC $\$ 4901$ et seq.)

- Hazardous Material Transportation Act (49 USC $\$ 703$ et seq.)

- Solid Waste Disposal Act as amended by the Resource Conservation and Recovery Act (42 USC $\S 6901$ et seq.)

- Executive Order 11988 (Floodplain Management)

- Executive Order 11990 (Protection of Wetlands)

- Executive Order 12898 (Environmental Justice)

I On December 19, 1996, Secretary of Energy, Hazel O'Leary, announced the intent of DOE to transition all DOE nuclear facilities into full regulation by the Nuclear Regulatory Commission in a little over 10 years. During this period the policies, procedures, and approaches of the NRC regulation of DOE facilities will be phased-in. 


\section{AGENCIES AND PERSONS CONSULTED}

DOE is required to review as guidance the most current U.S. Fish and Wildlife Service (USFWS) list for threatened and endangered species (T\&E). If, after reviewing the list, DOE determines that the proposed action would not impact any $T \& E$ species, DOE may determine or document that formal consultation with the USFWS is not required for an action. The Environmental Science and Research Foundation performs independent T\&E species reviews for DOE. They have advised DOE that a biological assessment is not needed for the proposed action as stated in Section 4.1.2.4. 


\section{REFERENCES}

1. Abbott, M. L., 1994, "Radiological Impacts Analysis for the Dry Cask Storage Project Environmental Assessment", MLA-22-92, October 13

2. Akers, D. W., E. L. Tolman, P. Kuan, and D. W. Golden, 1988, "Three-Mile Island Product Inventory Estimates," Nuclear Technology Journal, Vol. 87, August

3. Bishop, C. W., 1993, Water Resources, in: Irving. J. S., Environmental Resource Document for the INEL, Volumes 1 and 2, EGG-WMO-10279, EG\&G Idaho, July

4. Christensen, A. L., 1997, The INEEL TMI-2 Independent Spent Fuel Storage Installation at the Idaho Chemical Processing Plant, March

5. DOE, 1987, Characteristics of Spent Fuel, High-Level Waste, and Other Radioactive Wastes Which May Require Long-Term Storage, Office of Civilian Radioactive Waste Management, DOE/RW-0184

6. DOE, 1991a, Idaho National Engineering Laboratory Historical Dose Evaluation, DOE/ID-12119, Vol. 1, August

7. DOE, 1993a, Spent Fuel Working Group Report on Inventory and Storage of the Department's Spent Nuclear Fuel and other Reactor Irradiated Nuclear Material and their Environmental, Safety and Health Vulnerabilities, Volume 1, U. S. DOE, November

8. DOE, 1993b, The Idaho National Engineering Laboratory Site Environmental Report for Calendar Year 1992, DOE/1D-12082(91), June

9. DOE, 1993c, "Radiation Protection of the Public and the Environment," DOE 5400.5, Chg. 2, January 7

10. DOE, 1993d, INEL Stormwater Pollution Prevention Plan for Construction Activities, DOE/ID-10425, February 19

11. DOE, 1994a, Plan of Action to Resolve Spent Nuclear Fuel Vulnerabilities, Phase I, Volumes I and II, U.S. Department of Energy, Washington D.C., February

12. DOE, 1994b, Plan of Action to Resolve Spent Nuclear Fuel Vulnerabilities, Phase II, U.S. Department of Energy, Washington D.C., February

13. DOE, 1994c, Plan of Action to Resolve Spent Nuclear Fuel Vulnerabilities, Phase III, U.S. Department of Energy, Washington D.C., February

14. DOE, 1995, Department of Energy Programmatic Spent Nuclear Fuel Management and Idaho National Engineering Laboratory Environmental Restoration and Waste Management Programs Final Environmental Impact Statement, DOE/EIS-0203-F, April

15. DOE, 1995a, Record of Decision for the Department of Energy Programmatic Spent Nuclear Fuel Management and Idaho National Engineering Laboratory Environmental Restoration and Waste Management Programs Final Environmental Impact Statement. May 30

16. DOE, 1995b, "Settlement Agreement" between the State of Idaho, Department of the Navy, and the Department of Energy, Oct. 16

17. DOE, 1995c, Order 420.1 "Facility Safety," November 16

18. DOE, 1995d, Order 441.1 "Radiological Protection for DOE Activities" 
19. DOE, 1996a, Environmental Assessment, Test Area North Pool Stabilization Project, DOE/EA-1050, May

20. DOE, 1996b, 1995 INEL National Emission Standard for Hazardous Air Pollutants - Radionuclides, Annual Report, DOE/D-10342(95) June 1997

21. DOE 1996c The Safety Analysis Report for the INEL TMI-2 Independent Spent Fuel Storage Installation" Docket No. 72-20, Rev. 0, Oct. 1996

22. EPA, 1990, The Clean Air Act Assessment Package - 1988 (CAP-88), A Dose and Risk Assessment Methodology for Radionuclide Emissions to Air, Vol. 1, U.S. Environmental Protection Agency, Office of Radiation Programs, October

23. Fischer, L. E., et al., 1987, Shipping Container Response to Severe Highway and Railway Accident Conditions, NUREG/CR-4829

24. Idaho Administrative Procedures Act (IDAPA), 1996a, "Rules for the Control of Air Pollution In Idaho, "IDAPA 16.01.01.001 et. seq.

25. Idaho Administrative Procedures Act (IDAPA), 1996b, "Wastewater Land Application Permit Rules," IDAPA 16.01.17.001 et. seq.

26. Lacey, J., 1994, "Seismic Analysis of the Hot Shop Vestibule at TAN-607," EDF-TANO-94-24, EG\&G Idaho, June

27. LITCO 1995a, Idaho Chemical Processing Plant Safety Analysis Report Part I, Ch. I (INEL-94/022). March.

28. LITCO 1995b, Performance Specification, ICPP Interim Storage System (ISS) Facility for the Long Term Storage of TMI-2 Fuel Project, Rev 1, Project File No. 015239, May

29. LMITCO 1997, Spent Fuel Database "Record Summary Report" Current Inventory as of 6/1/96. Report Date: 7/25/97.

30. Mitchell, J. R., 1997 Transmittal of Information for a Permit to Construct Applicability Determination for the Idaho National Engineering and Environmental Laboratory, Three Mile Island Unit 2, Independent Spent Fuel Storage Installation Project, at the Idaho Chemical Processing Plant, JRM104-97, March 28

31. Palmer, J. O., 1995. 'Background on the Decision Not to Dry the TMI-2 Storage Canisters in Preparation for Interim Storage" LITCO, Letter No. AJP-02-95, Feb. 16

32. Peterson, H. K., 1991, Letter to S. K. Gray, EG\&G "Reevaluation of the Dry Cask Storage Environmental Concerns"Letter No. HKP-11-91, Nov. 8

33. Reed, W. G., R. N. Holmer, B. L. Ringe, and J. W. Ross, 1986, Archaeological Investigations on the INEL, Idaho State University, Swanson/Crabtree Anthropological Research Laboratory, Report of Investigations 86-4

34. Reynolds, T. L., 1993, Memorandum to S. K. Gray, Subject: “Pool Stabilization Project” July 9

35. Ringe, B. L., 1993, Memorandum to S. K. Gray, Subject: "Dry Cask Storage Project," INEL Cultural Resources Office, EG\&G Idaho, Inc., July 15

36. Rohrig, N. D., 1991, “TAN-607 Dose Estimates for Pool Draining Accident”, EDF-WMTO-91-07, July

37. Staley, C.S., 1996, "Dose to Maximally Exposed Individuals due to Potential Airborne Releases from the INEL Storage of the TMI-2 Fuel Project, "Engineering Design File EMA-96-001, LITCO, February 
38. Staley, C.S., 1997, "Doses to a Maximally Exposed Individuals due to Potential Airborne Releases from dewatering TMI-2 Fuel at Test Area North, "Engineering Design File EMA-97-002, LMITCO, January

39. Thorne, D. to S. K. Gray, 1995. Memorandum, Subject: "Assessment of the Potential Dose to INEL Workers from the Discharge of Tritiated Water in the TAN Pool to Disposal Ponds, "April 9,

40. Zohner, S. K., 1995 Letter to T. A. Solle, LITCO, NESHAP Evaluation of TMI-2 Fuel Dewatering, Transportation and Dry Storage SKZ-05-95. September 27

41. 10 CFR 20, Appendix A, "Protection Factors for Respirators"

42. 10 CFR 71, Section 55, "Packaging and Transportation of Radioactive Material, General Requirements for All Fissile Material Packages"

43. 10 CFR 72, "Licensing Requirements for the Independent Storage of Nuclear Fuel and High-Level Radioactive Waste,"

44. 10 CFR 835, "Occupational Radiation Protection,"

145. 10 CFR 1022 "Compliance With Floodplain/Wetlands Environmental Review Requirements"

46. 40 CFR 61, "National Emission Standards for Hazardous Air Pollutants," December

47. 40 CFR 260, "Hazardous Waste Management System: General"

48. 40 CFR 261, "Identification and Listing of Hazardous Wastes"

49. 40 CFR 262, "Standards Applicable to Generators of Hazardous Waste"

50. 40 CFR 263, "Transporters of Hazardous Waste"

51. 40 CFR 264, "Standards for Owners and Operators of Hazardous Waste Treatment, Storage and Disposal Facilities"

52. 40 CFR 265, "Interim Status Standards for Owners and Operators of Hazardous Waste Treatment, Storage and Disposal Facilities"

53. 40 CFR 268, "Land Disposal Restrictions,"

54. 40 CFR 122, "National Pollutant Discharge Elimination System," 